\title{
The Statherian itabirite-bearing sequence from the Morro Escuro Ridge, Santa Maria de Itabira, Minas Gerais, Brazil
}

\author{
Flávia Cristina Silveira Braga a, *, Carlos Alberto Rosière ${ }^{b}$, Gláucia Nascimento Queiroga c, \\ Vassily Khoury Rolim ${ }^{\mathrm{d}}$, João Orestes Schneider Santos ${ }^{\mathrm{e}}$, Neal Jesse McNaughton ${ }^{\mathrm{f}}$ \\ ${ }^{a}$ Graduate Program, Instituto de Geociências, Universidade Federal de Minas Gerais, Belo Horizonte, MG, Brazil \\ ${ }^{\mathrm{b}}$ Instituto de Geociências, Universidade Federal de Minas Gerais, Belo Horizonte, MG, Brazil \\ ${ }^{\mathrm{c}}$ Departamento de Geologia, Universidade Federal de Ouro Preto, Ouro Preto, MG, Brazil \\ d Graduate Program, Instituto de Geociências, Universidade Federal de Minas Gerais, Belo Horizonte, MG, Brazil \\ e Centre for Exploration Targeting, University of Western Australia, Perth, Australia \\ ${ }^{\mathrm{f}}$ Curtin University of Technology, Perth, Australia
}

\section{A R T I C L E I N F O}

\section{Article history:}

Received 8 June 2014

Accepted 18 December 2014

Available online 27 December 2014

\section{Keywords:}

Morro Escuro Ridge

Serro group

Itabirite

Geochemistry

\begin{abstract}
A B S T R A C T
The itabirite-bearing metasedimentary sequence from Morro Escuro Ridge comprises the basal units of the Espinhaço Supergroup and makes up a small tectonic inlier developed during one of the Brasiliano orogenic events (800-500 Ma), amongst horses of the Archean TTG gneisses, including sheared granites of the anorogenic Borrachudos Suite ( $1700 \mathrm{Ma})$. The metasedimentary rocks are comprised of low-to intermediate-amphibolite facies schists, quartzites, conglomerates and banded iron formation (itabirite) correlatable with the sequences of the Serro Group, which underlies the metasedimentary rocks of the Espinhaço Supergroup in the Serra da Serpentina Ridge. A maximum Statherian deposition age (1668 Ma) was established using SHRIMP U-Pb isotopic constraints on zircon grains from conglomerate and quartzite units overlying the itabirite. The itabirite is predominantly hematitic and its geochemical characteristics are typical of a Lake Superior-type BIF deposited in a platformal, suboxic to anoxic environment distant from Fe-bearing hydrothermal vents. Close to the contact zone with amphibolites of the Early Neoproterozoic Pedro Lessa mafic suite, an increase of the magnetite content and crystallization of metasomatic Mg-hornblende and Ce-allanite can be observed. These mineralogical changes developed preferentially along the igneous contact zone but are probably co-genetic with the formation of alteration haloes in zircon grains during the Neoproterozoic Brasiliano orogeny (506 $\pm 6 \mathrm{Ma})$.
\end{abstract}

๑ 2014 Elsevier Ltd. All rights reserved.

\section{Introduction}

The Morro Escuro Ridge (MER) and similar ridges are discontinuously distributed in a large area reaching from the eastern border of Quadrilátero Ferrífero up to the town of Serro (Fig. 1). These ridges follow an arcuate structural trend that varies from NW-SE, N-S to NE-SW bordering the eastern to southeastern part of the São Francisco Craton (Fig. 1). The

\footnotetext{
* Corresponding author.

E-mail addresses: flaviacsbraga@gmail.com (F.C. Silveira Braga), crosiere@gmail. com (C.A. Rosière), glauciaqueiroga@yahoo.com.br (G.N. Queiroga), vassily.rolim@ gmail.com (V.K. Rolim), orestes.santos@bigpond.com (J.O.S. Santos), n. mcnaughton@curtin.edu.au (N.J. McNaughton).
}

structural framework of these geomorphological units is defined by intercalated thrust slices of metasedimentary structural units and granite-gneissic rocks of the basement developed during the Brasiliano Orogen (Araçuaí Orogenic Belt - Noce et al., 2007). The metasedimentary outcropping units are comprised mainly of a layer of metamorphosed banded iron formation, referred to as itabirite, found between thick psamo-pelitic units which have also locally undergone metasomatism and hydrothermal alteration, but without the formation of large, economically important high-grade iron ore bodies ( $>64 \mathrm{wt} \% \mathrm{Fe}$ ). The increasing global demand for iron, however, has made unenriched, medium-graded banded iron formations ( $<40 \mathrm{wt} \% \mathrm{Fe}$ ), such as those found at the Morro Escuro and similar ridges, important targets for exploration. 


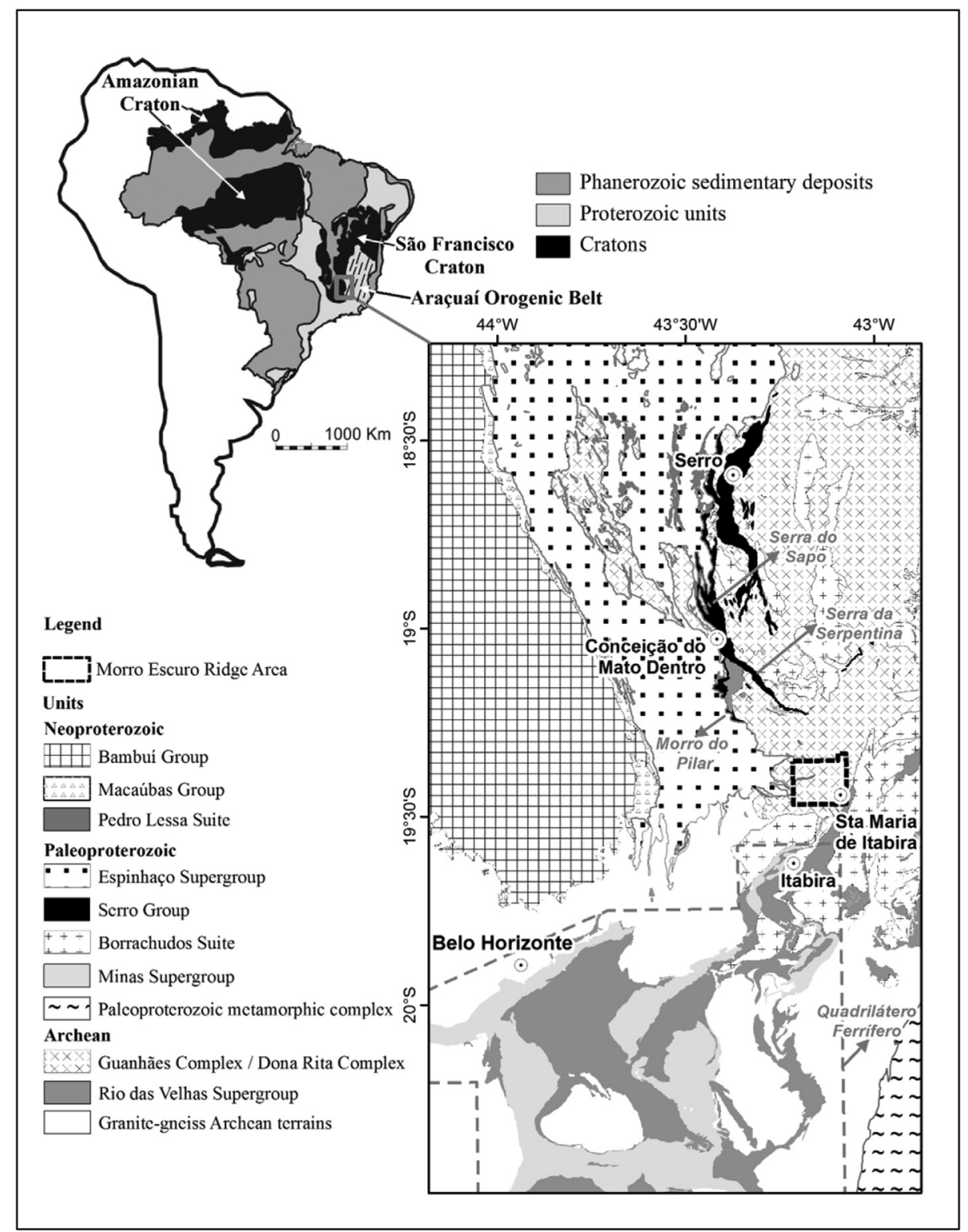

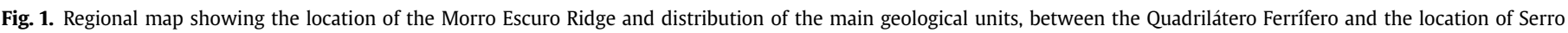
(based on Grossi-Sad et al., 1997; Pedrosa-Soares et al., 1994).

The age of these units and their depositional environment have been interpreted variously and controversially. Some authors, for instance, ascribe the Morro Escuro itabirite layer to the Paleoproterozoic Minas Supergroup (Itabira Group) or to the volcanosedimentary unit from the Guanhães Complex assemblage (Grossi-Sad et al., 1997; Pedrosa-Soares et al., 1994) of Archean age $(2867 \pm 10$ - Silva et al., 2002). Our recent results from field mapping in the MER, in combination with detailed petrographic, geochemical and isotopic studies of itabirite and its host rocks have allowed us to: 1) define a local stratigraphic column for that area (here called the Morro Escuro Ridge sequence) and distinguish it from the BIF-bearing Guanhães Complex and Minas Supergroup (2580 Ma to $2420 \mathrm{Ma}$ - Hartmann et al., 2006) from the Quadrilátero Ferrífero mining district; 2) compare, discuss and suggest a correlation at a regional scale with the Statherian Serro Group that underlies the Espinhaço Supergroup at the Serra da Serpentina Ridge located at ca. $35 \mathrm{~km}$ NE (Fig. 1); 3) deliver a preliminary interpretation regarding the physical and chemical transformations undergone by the BIFs during the Brasiliano orogeny.

\section{Regional geology}

\subsection{Structural setting}

The Morro Escuro and similar itabirite ridges are widespread along the western and southern border of the Guanhães Block (Alkmim et al., 2007), which is a wide expanse of the basement of the Neoproterozoic Araçuaí Orogenic Belt (Fig. 1). Top-to-west thrust faults and east-vergent backthrusts (Dussin, 1994) developed during the Brasiliano orogeny (800-500 Ma), juxtaposing allochthonous slices comprised by BIF-bearing metasedimentary sequences inserted between granitic bodies of the Paleoproterozoic Borrachudos Suite and Archean TTG gneisses of the crystalline basement (Fig. 1) (Grossi-Sad et al., 1997; Pedrosa-Soares et al., 1994).

\subsection{The crystalline basement}

Archean crystalline rocks from the Dona Rita and Guanhães complexes (Grossi-Sad et al., 1997) make up the basement of the 
São Francisco Craton (Fig. 1). The Guanhães Complex stretches over the central-eastern part of the state of Minas Gerais and is comprised mainly of an undivided assemblage of TTG (tonalite-trondhjemite-granodiorite) gneisses, migmatites and granitic bodies, commonly displaying mylonitic fabric, together with discontinuous strings of metasedimentary and metavolcanic rocks (Dussin et al., 2000; Noce et al., 2007). The Dona Rita Complex is a similar lithostratigraphic unit, indistinguishable from the Guanhães Complex, which crops out on the eastern border of the Craton (Guimarães, 1992; Grossi-Sad et al., 1997).

\subsection{Itabirite-containing basins in the Southern São Francisco Craton}

\subsubsection{The siderian Minas basin}

The Paleoproterozoic Minas Supergroup (2580 Ma to $2420 \mathrm{Ma}-$ Hartmann et al., 2006) is located SW of the study area, in the Quadrilátero Ferrífero mining district. It is largely composed of metamorphosed carbonate-rich platformal sequences as well as quartzites, metaconglomerates, phyllites, dolomites, and banded iron formations (itabirites) that host the largest and economically most important iron deposits in southern Brazil, including several high-grade ( $>60 \mathrm{wt} \% \mathrm{Fe}$ ) ore bodies (Rosière et al., 2008). The rocks of the Minas Supergroup are polydeformed and were affected by two main orogenic events the oldest one initiated at ca $2.1 \mathrm{Ga}$ (Alkmim and Marshak, 1998), in the end of the Rhyacian Period with posterior tectonic reworking during the Brasiliano collage (Brito-Neves et al., 2014), resulting in a roughly bi-directional (NE-SW, NW-SE) domal structural pattern. Itabirites occur in three compositionally distinct lithofacies, namely quartz itabirite, dolomite-itabirite, and amphibole-itabirite.

\subsubsection{The Statherian Espinhaço basin}

The Espinhaço Supergroup (Pflug, 1968; Schöll and Fogaça, 1979 ) is interpreted as being deposited in two younger intraplate basins of distinct ages: (i) the Lower Espinhaço Basin, which is marked by a volcano-sedimentary sequence with alluvial, fluvial and eolian sediments deposited from $1.68 \mathrm{Ga}$ to $1.80 \mathrm{Ga}$; and (ii) the overlying Upper Espinhaço rift-sag Basin, which has a maximum deposition age of 1192 Ma (Chemale Jr. et al., 2012). The shallow marine sedimentary rocks from the Lower Espinhaço Basin are underlain by itabirite-bearing psamo-pelitic units and ultramafic rocks. A U-Pb age of $1715 \pm 2$ Ma was obtained from the igneous zircon grains of interlayered metarhyolite bodies (Machado et al., 1989), but the stratigraphic arrangement has been controversial. According to Almeida-Abreu et al. (1989) and Almeida-Abreu and Renger (2002, 2007), these units belong to the Serro Group (Fig. 1), which comprises, from bottom to top, the Alvorada de Minas Ultramafic Suite, quartzites from the Jacém Formation, and two BIF-bearing psamo-pelitic sequences: the Serra do Sapo and Itapanhoacanga formations. Rolim and Rosière (2011) have recently proposed a new stratigraphic grouping that would delineate two individual upper and lower BIF units separated by a psamitic layer.

\subsection{Magmatic units}

Anorogenic granitic bodies of the Borrachudos Suite (Fig. 1) occur along the eastern border of the São Francisco Craton, and were emplaced during a Paleoproterozoic plutonic event. This unit was dated by Silva et al. (2002) at $1740 \pm 8 \mathrm{Ma}$ using SHRIMP U-Pb in zircon crystals, and by Dossin et al. (1993) at $1729 \pm 14$ Ma using the zircon Pb-evaporation method.

Amphibolitic rocks were dated by Machado et al. (1989) at $906 \pm 2 \mathrm{Ma}$, comprising the Pedro Lessa Suite associated with the rift volcanism of the Neoproterozoic Macaúbas Basin (Noce et al.,
1997). Younger, undeformed Mesozoic mafic dikes (120 Ma Silva et al., 1995) were intruded during Pangaea breakup.

\section{Sample selection and methodology}

Our fieldwork activities in the studied area included surface geological mapping with detailed work conducted along profiles transversal to the ridge structure that include the description of 258 waypoints and 31 diamond drill cores with the collection of 69 samples for the preparation of thin and polished sections.

Whole rock chemical analyses from 30 collected samples (10 granite-gneiss, 4 mafic rock and 16 iron formation) were accomplished at the ACME Labs using the ICP-ES (Inductively Coupled Plasma Emission Spectrometry) method for major oxide elements and the ICP-MS (Inductively Coupled Plasma Mass Spectroscopy) method for trace elements.

The chemical composition of several metamorphic minerals amphibole, biotite, garnet, staurolite and plagioclase - was obtained using the JEOL JXA-8900RL electronic microprobe, at $15 \mathrm{kV}$ accelerating voltage and 20 nA current, at the Instituto de Ciências Exatas of the Universidade Federal de Minas Gerais, for geothermobarometric calculations. The minerals were analyzed with WDS (Wavelength-Dispersive Spectrometers) for $\mathrm{SiO}_{2}, \mathrm{Al}_{2} \mathrm{O}_{3}, \mathrm{FeO}$, $\mathrm{MgO}, \mathrm{MnO}, \mathrm{CaO}, \mathrm{Na}_{2} \mathrm{O}, \mathrm{K}_{2} \mathrm{O}$ and $\mathrm{TiO}_{2}$. A microcline standard was used for the analyses of $\mathrm{Si}$ and $\mathrm{K}$, aluminum oxide $\left(\mathrm{Al}_{2} \mathrm{O}_{3}\right)$ for $\mathrm{Al}$, olivine for $\mathrm{Fe}$ and $\mathrm{Mn}$, hornblende for $\mathrm{Mg}$, anorthite for $\mathrm{Ca}$, albite for $\mathrm{Na}$ and rutile for $\mathrm{Ti}$.

The softwares TWQ 1.02 and TWQ 2.02 (Berman, 1991) were used for geothermobarometric calculations of maximum temperature $(\mathrm{T})$ and pressure $(\mathrm{P})$ with the purpose of establishing the metamorphic conditions using the Holand and Powell (1990) equations.

The Sm-Nd whole-rock isotopic analyses were carried out at the Laboratório de Geocronologia of the Universidade de Brasília on three amphibolite samples based on the method described by Gioia and Pimentel (2000). In this procedure, approximately $50 \mathrm{mg}$ of powder sample is mixed with a tracer solution of ${ }^{149} \mathrm{Sm}$ and ${ }^{150} \mathrm{Nd}$. The sample is dissolved in Savillex ${ }^{\circledR}$ capsules through successive acid attacks using $\mathrm{HF}, \mathrm{HNO}_{3}$ and $\mathrm{HCl}$. The contents of $\mathrm{Sm}$ and $\mathrm{Nd}$ were extracted through a cationic exchange column made of Teflon ${ }^{\odot}$ and packed with $\mathrm{LN}-\mathrm{Spec}$ resin (liquid resin HDEHP acid di(ethylhexyl) phosphoric acid impregnated by powdered Teflon). The fractions of Sm and Nd were deposited on double rhenium filament arrangements with nitric acid and analyzed in metallic form in static mode, using the mass spectrometer Finnigan MAT -v262 multi-collector. The uncertainties for the ratios of $\mathrm{Sm} / \mathrm{Nd}$ and ${ }^{143} \mathrm{Nd} /{ }^{144} \mathrm{Nd}$ are less than $\pm 0.5 \%(2 \sigma)$ and $\pm 0.005 \%(2 \sigma)$ respectively, based on repeated analyses using BHVO and BCR-1-1 international standards. The isotopic ratios are normalized for a ${ }^{146} \mathrm{Nd} /{ }^{144} \mathrm{Nd}$ value of 0.7219 and the disintegration constant used is $6.54 \times 10^{-12} \mathrm{a}^{-1}$.

SHRIMP (Sensitive High Resolution Ion Microprobe) U-Pb determinations of three samples were performed on detrital zircon crystals at Curtin University in Perth, Western Australia. The samples were processed with conventional crushing, grinding and screening methods at the LOPAG-DEGEO laboratory at the Universidade Federal de Ouro Preto. A heavy fraction concentration of 60-120 mesh was realized by panning. After the concentration, the three samples were sieved and washed to remove any very fine material (of clay and silt size). The 60-250 mesh fraction was treated with heavy liquid (TBE, tetra-bromo-ethane) to remove light minerals and a Frantz LB1 magnetic separator (to concentrate the less magnetic minerals such as zircon). Zircon was handpicked and organized in an epoxy mount, which was polished and carboncoated for SEM (Scanning Electron Microscope) study. Back- 
scattered images (BSE) were taken using a JEOL6400 SEM at the Centre for Analytical and Characterization Analyses at the University of Western Australia. Imaging of the zircon is critical for identifying internal features, such as the core and rims, and to avoid areas with high common lead content (inclusions, fractures, and metamict areas). Epoxy mounts (UWA 07-03) were coated with gold for SHRIMP analyses. Most SHRIMP analytical spots were in the diameter range of $20-30 \mu \mathrm{m}$ but the analyses of hydrothermal zircon used a spot size of only $10 \mu \mathrm{m}$. Four scans were used for each spot analysis of detrital zircon and seven scans during the analyses of hydrothermal minerals. The following masses were analyzed for zircon: $\left({ }^{196} \mathrm{Zr}_{2} \mathrm{O},{ }^{204} \mathrm{~Pb}\right.$, background, ${ }^{206} \mathrm{~Pb},{ }^{207} \mathrm{~Pb},{ }^{208} \mathrm{~Pb},{ }^{238} \mathrm{U}$, ${ }^{248} \mathrm{ThO},{ }^{254} \mathrm{UO}$ ), as well as ${ }^{200}$ TixOy, ${ }^{204} \mathrm{~Pb}$, background, ${ }^{206} \mathrm{~Pb},{ }^{207} \mathrm{~Pb}$, ${ }^{208} \mathrm{~Pb},{ }^{238} \mathrm{U},{ }^{248} \mathrm{ThO}$, and ${ }^{254} \mathrm{UO}$. The standards D23 and NBS611 were used to identify the position of the peak of the mass ${ }^{204} \mathrm{~Pb}$, whereas the calibration of the $\mathrm{U}$ content and the $\mathrm{Pb} / \mathrm{U}$ ratio were conducted using the zircon standard BR266 (559 Ma, 903 ppm U). The ${ }^{207} \mathrm{~Pb} /{ }^{206} \mathrm{~Pb}$ ages are used for all detrital grains, but the ${ }^{206} \mathrm{~Pb} /{ }^{238} \mathrm{U}$ ages are selected for hydrothermal zircon. Most of the data are concordant; the discordant data have been grouped with adjacent populations. All data on detrital zircon with common lead correction greater than $1 \%$ were rejected during the first scan. The uncertainties of individual ages are quoted at $1 \sigma$ level, whereas the ages plotted are calculated at $2 \sigma$ levels (about 95\% confidence). SHRIMP data were reduced using SQUID software (Ludwig, 2001) and plots were prepared using ISOPLOT/Ex (Ludwig, 2003).

\section{Geology of the Morro Escuro Ridge inlier}

\subsection{Tectonic structure}

The MER is a small ENE-WSW elongated allochthonous shearzone-bound inlier block, located between slices of the Archean basal Guanhães/Dona Rita Complex, and the Paleoproterozoic
Borrachudos Suite. The internal structure of the inlier is controlled by three sets of NE-SW trending folds (Fig. 2), which nucleated as fault propagation folds in three progressive deformation stages (D1, D2 and D3) during the Brasiliano orogeny (Pagung de Carvalho et al., 2014). The thrust faults verge towards the SE, differing from the general trend of the $\mathrm{W}$-facing fabric of the eastern border of the Espinhaço Range.

\subsection{Lithostratigraphic units}

\subsubsection{The Archean gneissic complex}

TTG-type orthogneisses that crop out in the surroundings of the MER area are correlated with the Archean Guanhães/Dona Rita Complex (Guimarães, 1992) and interpreted as part of the basement of the metasedimentary rocks of the MER sequence. These rocks exhibit a medium grain size $(0.01-1 \mathrm{~mm})$, with granoblastic to granolepidoblastic fabric. The main minerals are quartz, plagioclase, microcline, muscovite and biotite. The accessories are chlorite, zircon, apatite, titanite, allanite, epidote, clinozoisite, rutile and opaque minerals (magnetite, hematite, ilmenite, pyrite, chalcopyrite, pyrrhotite).

\subsubsection{The Borrachudos Suite}

Structural slices of granite belonging to the Borrachudos Suite are also intercalated with the MER sequence. Such rocks exhibit textural features and a mineralogical composition very similar to those of the Guanhães/Dona Rita Complex, but with a distinct geochemical signature that indicates intrusion in an intraplate setting, as will be discussed further below.

\subsubsection{The Morro Escuro Ridge sequence}

$\mathrm{NE}-\mathrm{SW}$ striking conformable strata comprise the supracrustal rocks informally named as the Morro Escuro Ridge sequence and subdivided into four meta-lithostratigraphic units (Fig. 3).

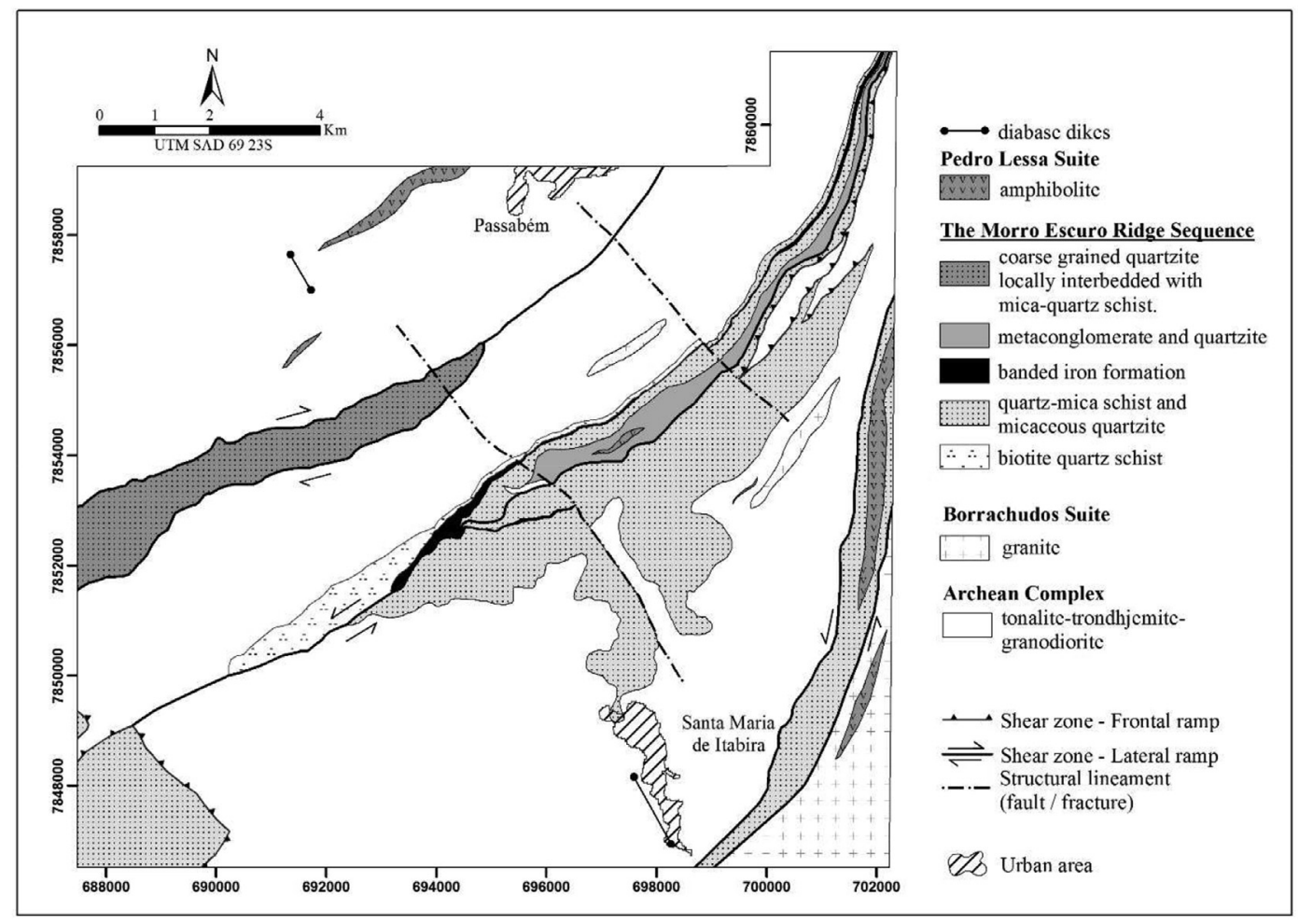

Fig. 2. Geologic map of the Morro Escuro Ridge.

Adapted from Pagung de Carvalho et al., 2014. 
Biotite-quartz schist unit: A wide mineralogical variety of aluminous schists comprise the lowest unit of the MER sequence, always in direct contact with the basement (Fig. 2). The fabric is dominantly granoblastic and lepidoblastic, but nematoblastic domains were also observed, with the development of a continuous to anastomosed schistosity that is locally crenulated. Biotite and quartz are the main components of the schists, although garnet, carbonaceous matter (graphite?), plagioclase, staurolite, amphibole, tourmaline, carbonate, muscovite, chlorite, ilmenite and magnetite can also be found as rock-forming minerals. Titanite, sulfides (chalcopyrite, pyrrhotite, pyrite, arsenopyrite, sphalerite), zircon, apatite, hematite, ilmenite, and epidote are accessory minerals. Several lithotypes can be distinguished by their mineral assemblages, such as garnet-biotite-quartz schist, biotite-garnet-staurolite-quartz carbonaceous schist, garnet-biotite-amphibole-quartz carbonaceous schist, magnetite-biotite-quartz schist, tourmaline-biotite-quartz schist and scattered lenses of amphibole-carbonate schist (Fig. 3).

The garnet composition is predominantly almandine (molar fraction 63.54-84.07), pyrope (6.28-24.51), grossularite (0.77-21.70) and spessartine (0-8.12). Biotite is Mg-rich. The analyzed plagioclase crystals have anorthite composition in the biotite-garnet-amphibole-quartz carbonaceous schists and andesine composition in the garnet-biotite-quartz schists. Magnesian hornblende is the most frequent amphibole with subordinate tschermakite (Leake et al., 1997).

The carbonatic schist comprises calcite, amphibole (tremoliteactinolite series) and ilmenite with hematite exsolution lamellae. The accessory minerals are sulfides (pyrrhotite, chalcopyrite, pyrite, arsenopyrite), magnetite, hematite and titanite.

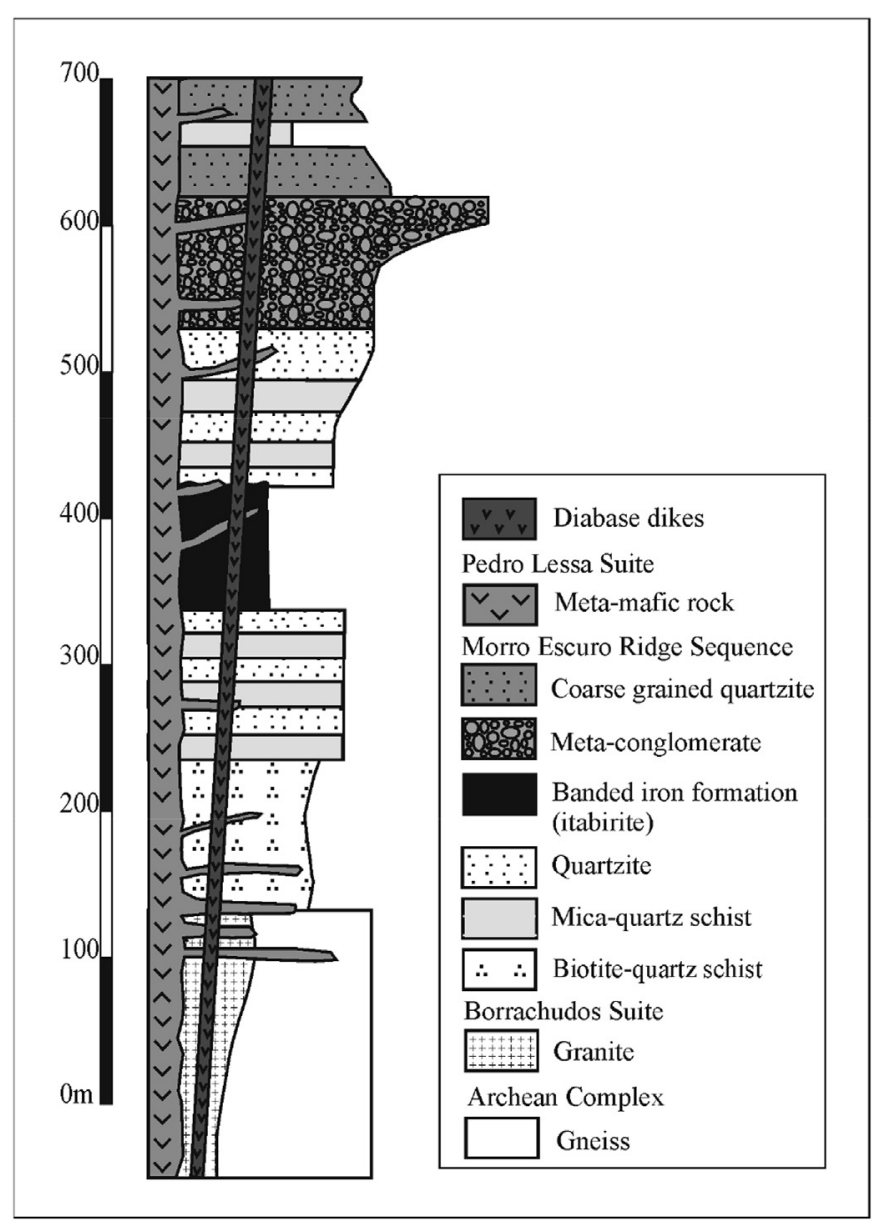

Fig. 3. Simplified lithostratigraphic column of the Morro Escuro Ridge inlier.
Lower quartzitic unit: This unit comprises mica-quartz schist and quartzite layers that grade toward ferruginous schist near the contact with the overlying itabirite (Fig. 3). The biotite-quartz schists are fineto medium-grained $(0.01 \mathrm{~mm}-1.0 \mathrm{~mm})$, showing lepidoblastic fabric. The rock-forming minerals are quartz, muscovite, biotite, kyanite and, locally, epidote, hematite (lamellar, granular), martite, magnetite and carbonate. The accessory minerals are ilmenite, apatite, tourmaline, zircon, titanite, chlorite and clinozoisite.

Upper quartzitic unit: The upper boundary of the overlying itabirite layer is defined by repeating mica-quartz schists and quartzite layers covered by coarse-grained quartzite (the diameter of grains reaches $0.5 \mathrm{~cm}$ ). There is an intercalation of metaconglomerate with quartzose matrix and sub-rounded clasts of quartz, quartzite and iron formation with low sphericity. The main minerals in the matrix of the conglomerate are quartz, muscovite, kyanite, iron oxides (mainly lamellar hematite and magnetite) and, rarely, hornblende. The accessory minerals are zircon, hematite, apatite and epidote.

Banded Iron Formation unit: Banded iron formation occurs in the MER as a NE-SW trending layer that, together with the metaconglomerates, supports the ridge (Figs. 3, 4 and 5A). Considering the metamorphic grade of this rock, we have used in the present paper the term itabirite as proposed by Rosière et al. (2008) and Hagemann et al. (2008).

The primary banding of the iron formation is commonly transposed with extensive obliteration of sedimentary/diagenetic structures by axial plane schistosity (Fig. 5B and C) and the development of a structural layering defined by the alternation of millimetric bands of quartz and iron oxides (hematite and magnetite). Centimetric to millimetric intrafolial folds are ubiquitous (Fig. 5B). The foliation is cut across obliquely by shear zones with a thickness of $\mathrm{mm}$ or $\mathrm{cm}$ and a length of several meters, which commonly host lenticular bodies of quartz-free, high-grade ( $64 \mathrm{wt} \% \mathrm{Fe})$ schistose ore. Grain size varies from fine to medium $(0.01 \mathrm{~mm}-1.0 \mathrm{~mm})$.

Textural and mineralogical characteristics of the Morro Escuro itabirite are homogeneous, distinguishing them from the Cauê Formation of Quadrilátero Ferrífero (Rosière and Chemale Jr., 2000), which exhibits a wider variety of compositional facies. Nevertheless, they are identical to the quartz itabirite of the Serro Group as observed in the Serra da Serpentina (Rolim and Rosière, 2011; Dossin, 1985; Dossin et al., 1987) and Serra do Sapo ridges (Zacchi, 2010). The fabric of the iron formation is mainly schistose with subordinate granoblastic domains. Granoblastic ore is composed of equidimensional crystals with triple-junction and straight-grain boundaries. However, anhedral hematite crystals with lobate embayments and inequidimensional irregular intergrowths with martite are also present. Schistose domains are composed of elongated platy crystals (Fig. 6). Magnetite and amphiboles usually occur close to the contact zones with mafic dikes.

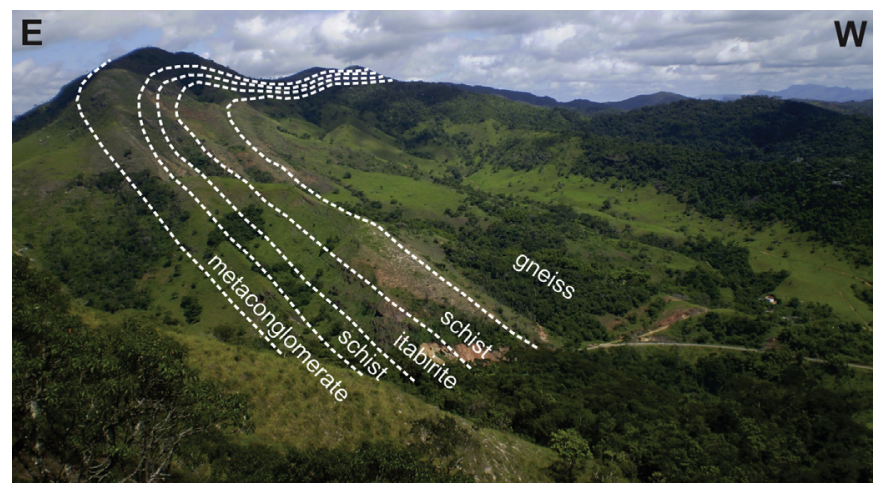

Fig. 4. East-west view of the Morro Escuro Ridge, showing the distribution of the lithostratigraphic units. 

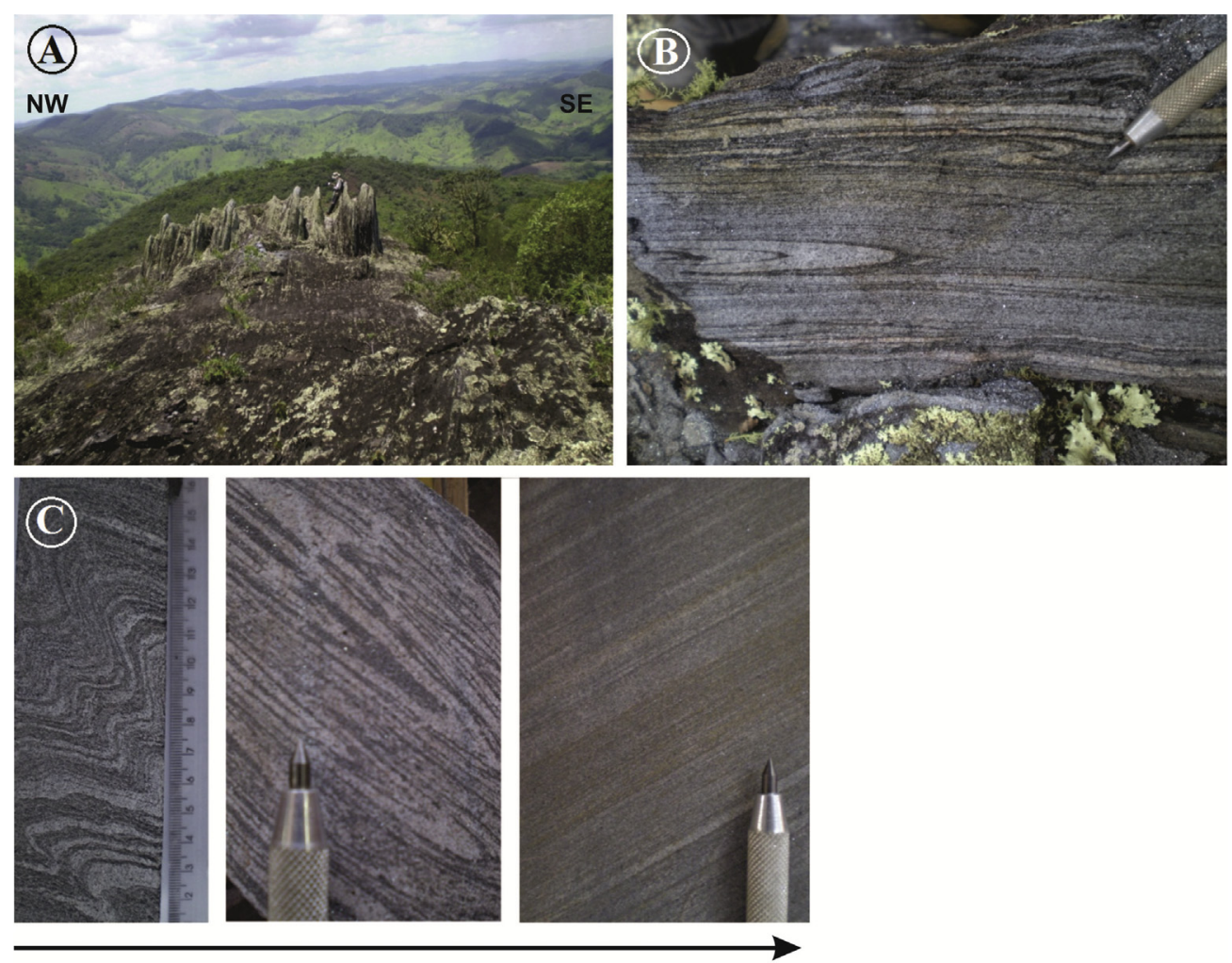

increasing degree of transposition

Fig. 5. Macroscopic characteristics of the Morro Escuro itabirite. (A) Itabirite outcrop in the southern portion of the Morro Escuro Ridge (UTM-693721/7852255); (B) Detail depicting millimetric banding with intrafolial folds (UTM-695335/7853778); (C) Variation in thickness of bands from left to right indicates the transposition and obliteration of the itabirite layering to an homogeneous foliation.
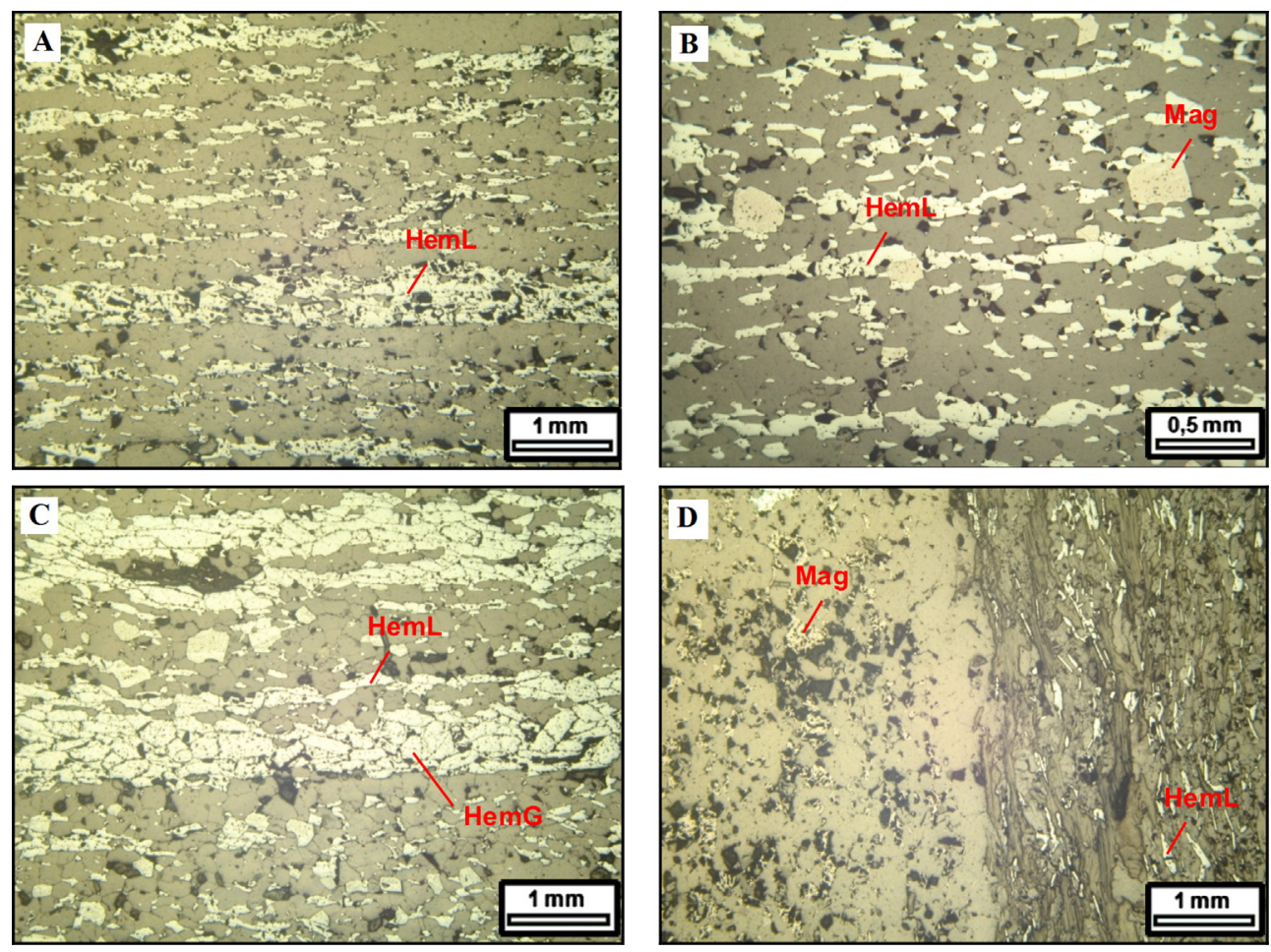

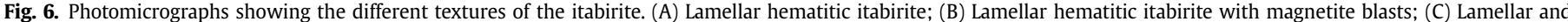

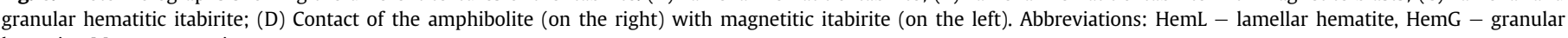
hematite, Mag - magnetite. 
Table 1

Synkinematic mineral assemblages and metamorphic facies of each lithostratigraphic unit of the Morro Escuro Ridge. Abbreviations: Qz - quartz, Pl - plagioclase, Ms - muscovite, Bt - biotite, Mc - microcline, Ep - epidote, Grt - garnet, Ky kyanite, St - staurolite, $\mathrm{Gr}$ - graphite, $\mathrm{Hbl}$ - hornblende, $\mathrm{Cb}$ - carbonate, $\mathrm{Tr}$ tremolite, Act - actinolite, Hem - hematite, Mag - magnetite.

\begin{tabular}{|c|c|c|}
\hline Unit & Paragenesis & Facies \\
\hline $\begin{array}{l}\text { Archean Complex and } \\
\text { Borrachudos Suite }\end{array}$ & 1) $\mathrm{Qz}+\mathrm{Pl}+\mathrm{Mc}+\mathrm{Bt}+\mathrm{Ms} \pm \mathrm{Ep}$ & Amphibolite \\
\hline Biotite-quartz schist & $\begin{array}{l}\text { 1) } \mathrm{Qz}+\mathrm{Bt}+\mathrm{Grt}+\mathrm{Ky}+\mathrm{Ms} \\
\text { 2) } \mathrm{Qz}+\mathrm{St}+\mathrm{Grt}+\mathrm{Bt}+\mathrm{Gr} \\
\text { 3) } \mathrm{Qz}+\mathrm{Hbl}+\mathrm{Gr}+\mathrm{Grt}+\mathrm{Bt}+\mathrm{Ms}+\mathrm{Pl} \\
\text { 4) } \mathrm{Qz}+\mathrm{Bt}+\mathrm{Pl} \\
\text { 5) } \mathrm{Qz}+\mathrm{Bt}+\mathrm{Grt}+\mathrm{Ep} \\
\text { 6) } \mathrm{Qz}+\mathrm{Bt}+\mathrm{Grt}+\mathrm{Pl}+\mathrm{Gr}+\mathrm{St}+\mathrm{Ep} \\
\text { 7) } \mathrm{Cb}+\mathrm{Tr} / \mathrm{Act}\end{array}$ & Amphibolite \\
\hline Mica-quartz schist & $\begin{array}{l}\text { 1) } \mathrm{Qz}+\mathrm{Ms}+\mathrm{Ep} \pm \mathrm{Bt} \\
\text { 2) } \mathrm{Qz}+\mathrm{Ms}+\mathrm{Ky} \pm \mathrm{Ep}\end{array}$ & $\begin{array}{l}\text { Greenschist to } \\
\text { Amphibolite }\end{array}$ \\
\hline Itabirite & 1) $\mathrm{Qz}+\mathrm{Hem}+\mathrm{Mag} \pm \mathrm{Hbl}$ & Amphibolite \\
\hline Metaconclomerate & $\begin{array}{l}\text { 1) } \mathrm{Qz}+\mathrm{Ms} \pm \mathrm{Ep} \pm \mathrm{Hbl} \\
\text { 2) } \mathrm{Qz}+\mathrm{Ms}+\mathrm{Ky}+\mathrm{Hbl}\end{array}$ & Amphibolite \\
\hline Amphibolite & 1) $\mathrm{Hbl}+\mathrm{Pl}+\mathrm{Qz} \pm \mathrm{Bt} \pm \mathrm{Ep}$ & Amphibolite \\
\hline
\end{tabular}

Magnetite appears as relicts in martite or as subhedral crystals $(0.01 \mathrm{~mm}-4.0 \mathrm{~mm}$ of diameter) grown in a finer-banded hematite matrix (Fig. 6D). Magnesium-hornblende and, subordinately, tschermakite and epidote, comprise $<10$ vol\% of the rock. The accessory minerals of the itabirite are sericite, chlorite, apatite and, very rarely, rutile, epidote (Ce-allanite), pyrite and chalcopyrite.

\subsubsection{Intrusive mafic rocks}

There are two generations of intrusive mafic rocks in the studied area (Fig. 3). The oldest is represented by tabular-shaped bodies of orthoamphibolite of the Pedro Lessa Suite (Dussin, 1994), which are in structural contact with all previously described units. The amphibolite is fine-to medium-grained, rarely coarse-grained, with a nematogranoblastic texture. It is composed mainly of hornblende, plagioclase, quartz, biotite, epidote, titanite, and ilmenite with hematite exsolution lamellae. The accessory minerals are sulfides (pyrite, chalcopyrite, pyrrhotite, arsenopyrite, pentlandite, sphalerite and bornite), magnetite, apatite, allanite, zircon and rutile.

Massive dark green isotropic gabbroic dikes comprise the younger set of undeformed Mesozoic mafic dikes (Silva et al., 1995) that preferentially cut through the gneiss. They exhibit a fine phaneritic, subophitic, equigranular fabric and are mainly composed of plagioclase, clinopyroxene, olivine and opaque minerals.

\section{Metamorphism}

The mineral assemblages (Table 1) in the different lithostratigraphic units consistently constrain the regional metamorphic grade to the amphibolite facies. The association staurolite \pm garnet \pm biotite \pm muscovite \pm quartz \pm plagioclase that defines the $S_{1}$-foliation of the pelitic schists, indicates conditions of the staurolite and, more rarely, the kyanite zone (Yardley, 2004).
Geothermobarometric calculations were based on microanalysis of the core of synkinematic garnet, biotite, plagioclase and amphibole crystals selected from three samples of biotite schist (Appendix A). Three independent reactions were obtained from the plagioclase-bearing carbonaceous schist (Sample 010-133,35, Table 2), exhibiting a minimum temperature of $512^{\circ} \mathrm{C}\left( \pm 50^{\circ} \mathrm{C}\right)$ and a maximum pressure of $5.9 \pm 1 \mathrm{kbar}$ (Fig. 7). Calculations from the other samples (Table 2 ) delivered a single reaction and a maximum temperature of $560^{\circ} \mathrm{C}\left( \pm 50^{\circ} \mathrm{C}\right)$. These values also indicate that the MER metasedimentary rocks experienced low-to intermediateamphibolite facies conditions.

\section{Geochemistry of the basement}

All granitic rocks that crop out in the MER and surroundings are strongly foliated and exhibit similar textural features and mineral assemblages, but could be distinguished based on their geochemical characteristics (Appendix B - chemical results). In the Rb vs. Y + Nb diagram (Fig. 8) after Pearce et al. (1984) one set of rocks plot largely in the WPG field (within-plates - intraplate granites), similar to the results from other granite bodies from the Borrachudos Suite (Dussin, 1994; Fernandes, 2001; Oliveira, 2002). The other points fall distinctly within the VAG (volcanic arc granites) field and indicate a distinct origin for the orthogneisses that are therefore ascribed to the basal Archean Complex (Guanhães/Dona Rita complexes) (Fig. 8).

The chondrite-normalized REE spidergrams for the different granitic rocks from the MER also exhibit very distinctive patterns: $\Sigma$ REE values for the WPG granite data range from 164.0 to 1050.1. The plots display a strong negative Eu anomaly $\left(\mathrm{Eu} / \mathrm{Eu}^{*}(\mathrm{CN})=\mathrm{Eu}_{(\mathrm{CN})} /\right.$ $\left.\mathrm{Sm}_{(\mathrm{CN})}+\mathrm{Gd}_{(\mathrm{CN})}\right)$, varying from 0.07 to 0.24 , and a relative enrichment of the $\operatorname{LREE}\left(\mathrm{La} / \mathrm{Yb}_{(\mathrm{CN})}\right.$ ratio) that fluctuates between 4.48 and 14.25. These values are similar to those reported by several authors (e.g. Dussin, 1994; Fernandes, 2001; Oliveira, 2002), for the typical granites from the Borrachudos Suite (Fig. 9). Distinctively, the samples that plot in the VAG field exhibit a less pronounced Eu anomaly $(0.31-0.49)$, higher $\mathrm{La} / \mathrm{Yb}_{(\mathrm{CN})}$ ratios $(10.49-150.85)$ and smaller $\Sigma$ REE values (51.0-289.4).

\section{Geochemistry of the itabirite}

Whole-rock chemical analyses of the itabirite from the MER were carried out on 16 drill core samples, collected below the weathering zone (Appendix C). The $\mathrm{SiO}_{2}$ and $\mathrm{Fe}_{2} \mathrm{O}_{3}$ content varies from 47.9 to $67.8 \mathrm{wt} \%$ and from 28.5 to $51.4 \mathrm{wt} \%$, respectively, similar to other BIFs worldwide (see Gutzmer et al., 2008 and references therein). The corresponding $\mathrm{Fe}_{\text {total }}$ content varies from 19.9 to $36.0 \mathrm{wt} \%$. According to Klein (2005), the average bulk chemistry of unenriched BIFs from the Archean and the Paleoproterozoic are always found to be similar, with $\mathrm{Fe}_{\text {total }}$ ranging from about 20 to 40 wt $\%$. The $\mathrm{CaO}, \mathrm{MgO}, \mathrm{MnO}, \mathrm{Al}_{2} \mathrm{O}_{3}, \mathrm{Na}_{2} \mathrm{O}, \mathrm{K}_{2} \mathrm{O}, \mathrm{P}_{2} \mathrm{O}_{5}, \mathrm{TiO}_{2}, \mathrm{Cr}_{2} \mathrm{O}_{3}$ contents are less than $1 \mathrm{wt} \%$. In most samples, the $\mathrm{MgO}, \mathrm{Na}_{2} \mathrm{O}, \mathrm{K}_{2} \mathrm{O}$ $(<0.01 \%)$ and $\mathrm{Cr}_{2} \mathrm{O}_{3}(<0.002 \%)$ values are below the detection limit (Appendix C). Two samples (008-701 and 009-001- Fig. 10) collected near the contact layer with the amphibolite dikes contain magnesian hornblende and display anomalously high grades of

Table 2

Geothermobarometric results obtained in three samples of biotite-quartz schist.

\begin{tabular}{|c|c|c|c|c|}
\hline Sample code & Rock & Analyzed minerals & Temperature $\left({ }^{\circ} \mathrm{C}\right)$ & Pressure (Kbar) \\
\hline $001-106,15$ & biotite-garnet-staurolite-quartz schist carbonaceous & garnet/biotite & $530-550$ & - \\
\hline $010-501$ & garnet-biotite-quartz schist with plagioclase & plagioclase/garnet/biotite & $530-560$ & - \\
\hline $010-133,35$ & $\begin{array}{l}\text { biotite-garnet-amphibole-quartz carbonaceous schist } \\
\text { with plagioclase }\end{array}$ & garnet/amphibole/biotite/plagioclase & 512 & 5.9 \\
\hline
\end{tabular}




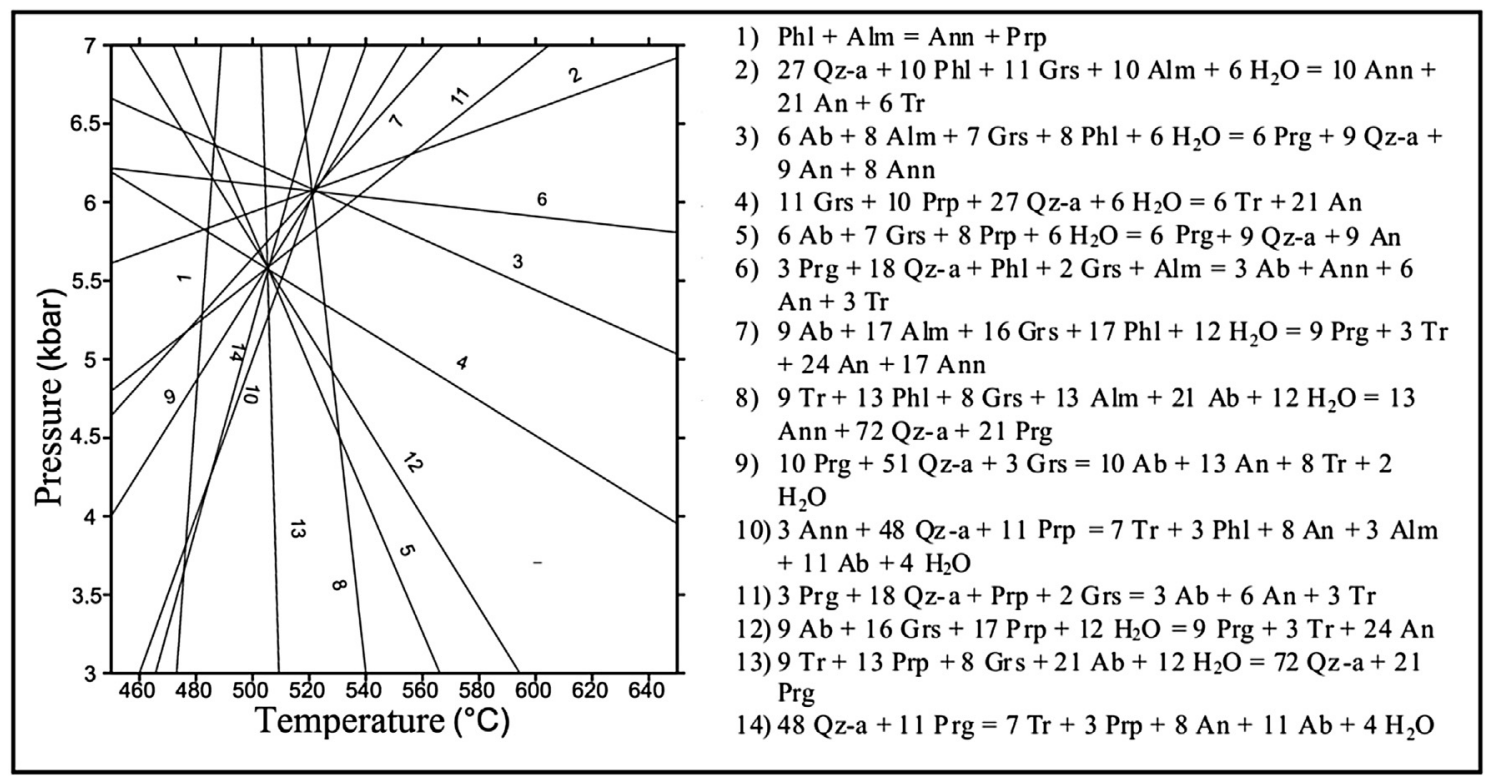

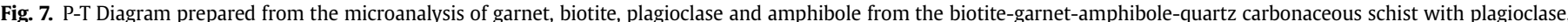

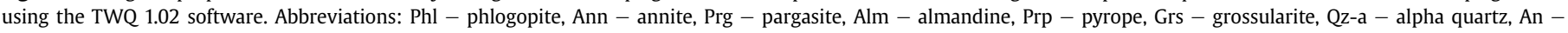
anorthite, $\mathrm{Ab}$ - albite, $\mathrm{Tr}$ - tremolite.

$\mathrm{MgO}, \mathrm{Al}_{2} \mathrm{O}_{3}, \mathrm{Na}_{2} \mathrm{O}$ and $\mathrm{K}_{2} \mathrm{O}$, which indicate metassomatic alteration of the itabirite.

The large variations in the Fe content of the highly deformed MER itabirite may be the result of two distinct factors: 1) the primary composition of the BIF; 2) selective leaching of quartz (or carbonates) supported by localized pressure solution as an effective deformation mechanism. There is much evidence of metasomatism and hydrothermal alteration in the area as discussed below, but without any significant Fe-enrichment. Some deposits of friable intermediate-to high-grade $(50-60 \mathrm{wt} \% \mathrm{Fe})$ iron ore on the eastern border of the Quadrilátero Ferrífero district have undergone considerable enrichment by pressure solution along shear zones, which was further enhanced by weathering and selective erosion (elutriation) of the fine recrystallized quartz grains along the foliation planes (Rosière et al., 2008), but this is not the case of the MER itabirite, where supergene enrichment was ineffective.

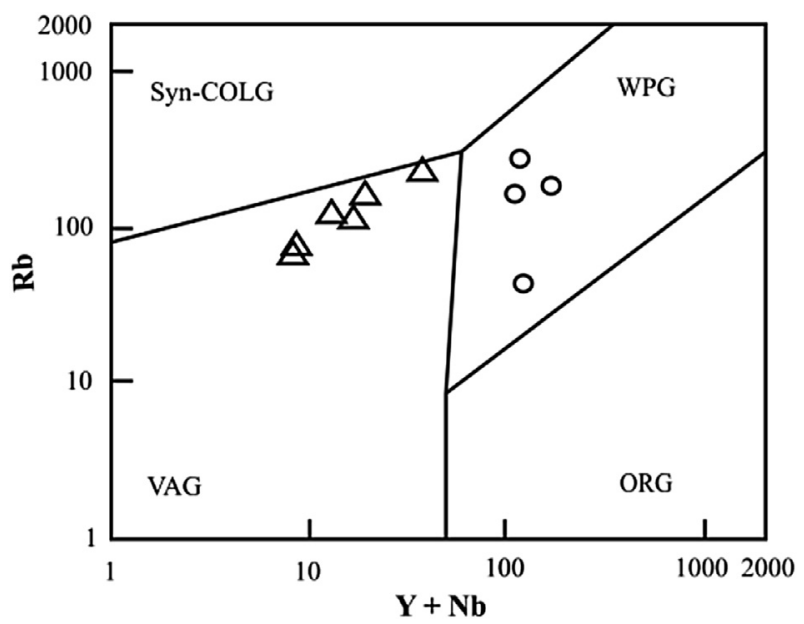

Fig. 8. $\mathrm{Rb}$ vs. $(\mathrm{Y}+\mathrm{Nb}$ ) Diagram for geotectonic classification (Pearce et al., 1984). Circles represent granites of the Borrachudos Suite sampled at the MER; the data fall within the WPG field (intraplate granites). Data points from Archean Complex (triangles) fall within the VAG field (volcanic arc granites).

\subsection{Rare earth elements}

Rare-earth elements (REE) are useful as pathfinders of the deposition environment of BIF, due to their low mobility during metamorphism (e.g. Taylor and McLennan, 1985; Elderfield and Sholkovitz, 1987; McLennan and Taylor, 1991), except in cases of metasomatism or when the fluid/rock ratio is very high (e.g Elderfield and Sholkovitz, 1987; Michard, 1989). The calculated

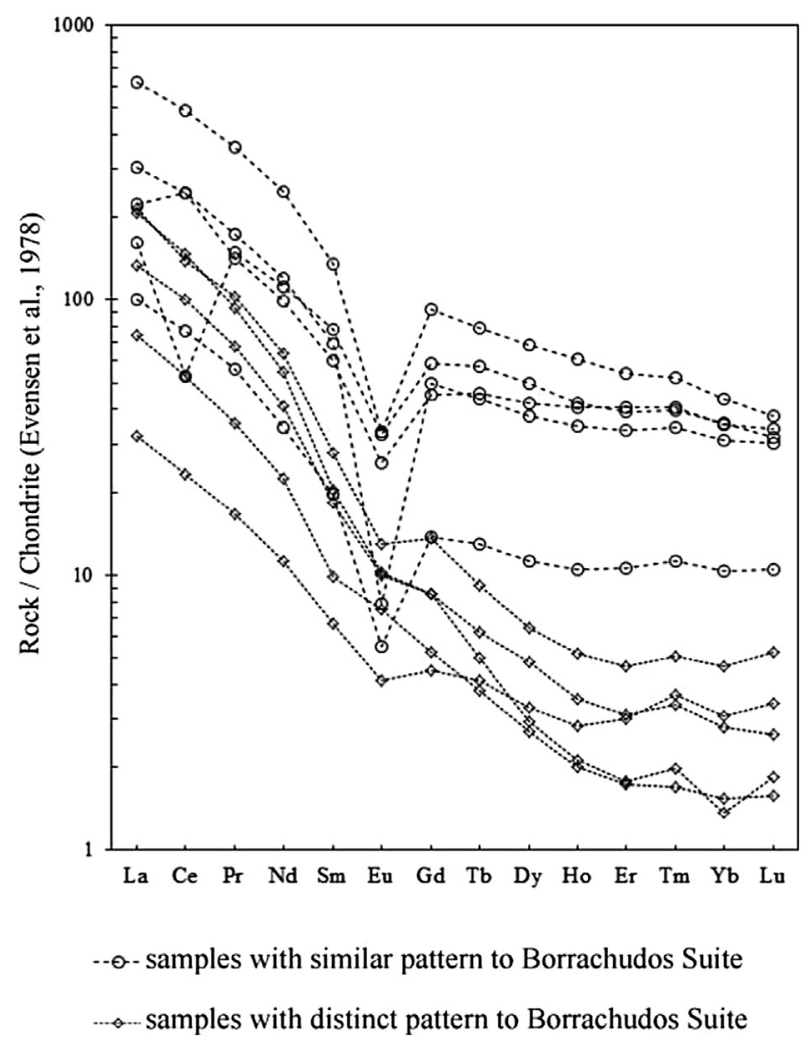

Fig. 9. Chondrite-normalized REE spidergrams (Evensen et al., 1978) of granites and basement gneiss. 


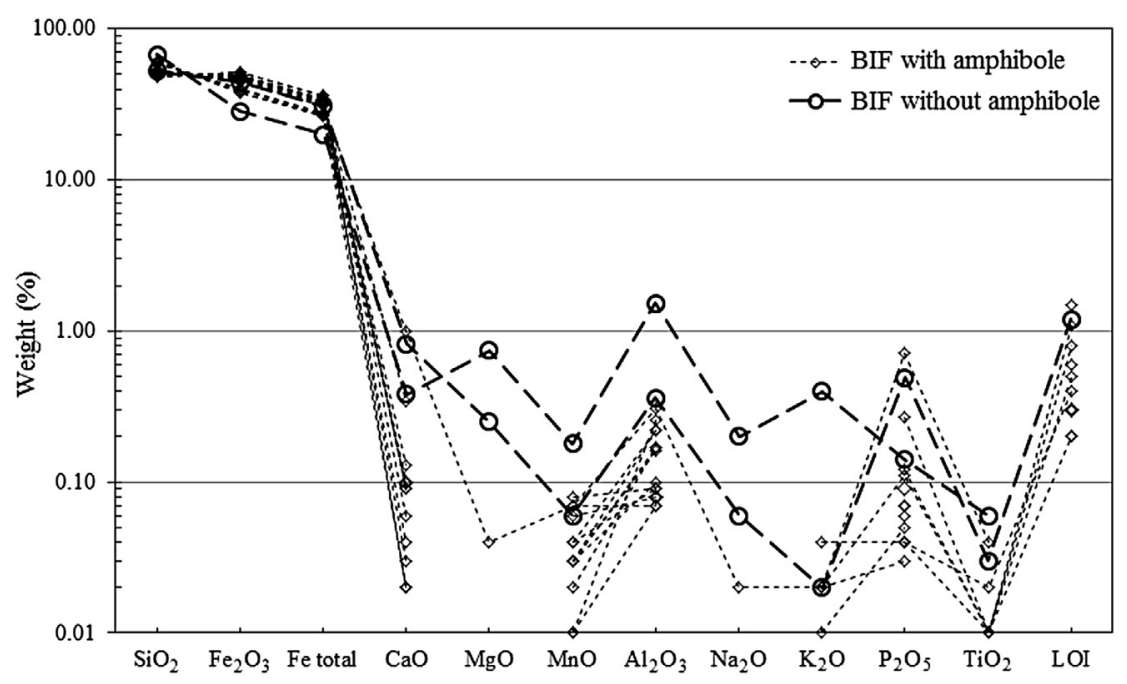

Fig. 10. Major whole rock oxide element content (wt\%) of the itabirite from Morro Escuro Ridge.

$\sum \mathrm{REE}+\mathrm{Y}$ (rare-earth elements plus yttrium) values for the Morro Escuro itabirite vary from 2.0 to $126.5 \mathrm{ppm}$. The highest values Fig. 11, Appendix C) were detected in the Mg-hornblende-bearing samples from the amphibolite contact zone (see above).

Chondrite-normalized (Taylor and McLennan, 1985) REE + Y spidergrams from the Morro Escuro itabirite display an anomalously high LREE/HREE ratio $\left((\operatorname{Pr} / \mathrm{Yb})_{(\mathrm{CN})}=0.57-4.03\right)$, as depicted in Fig. $11 \mathrm{~A}$. The $\mathrm{Eu}$ anomaly is slightly negative (Eu/ $\left.\mathrm{Eu}^{*}(\mathrm{CN})=0.27-0.65\right)$. PAAS - normalized (Post-Archaean Average Australian Sedimentary Rocks - McLennan, 1989) diagrams exhibit the typical relative HREE enrichment $\left((\mathrm{Pr} / \mathrm{Yb})_{(\mathrm{SN})}=0.10-0.71\right.$, Fig. 11B) and, in most cases, a positive but weak Eu anomaly (Eu/ $\mathrm{Eu}^{*}{ }_{(\mathrm{SN})}=0.90-1.91$ ) with an average of 1.6 , close to the value of 1.5 which is considered by Planavsky et al. (2010) to be characteristic of late Paleoproterozoic iron formations.

The shale-normalized $\mathrm{Ce}$ anomaly is slightly negative, close to 1 $\left(\mathrm{Ce} / \mathrm{Ce}^{*}{ }_{(\mathrm{SN})}=0.66-5.86\right)$ and independent of the $\mathrm{Al}_{2} \mathrm{O}_{3}$ content, but it may show positive values in Ce-allanite-bearing samples (samples 009-001 and 007-701 - Appendix C). The discriminative binary plot of $\mathrm{Ce} / \mathrm{Ce}^{*}{ }_{(\mathrm{SN})}$ vs. $\operatorname{Pr} / \operatorname{Pr}^{*}{ }_{(\mathrm{SN})}$ (Bau and Dulsky, 1996)

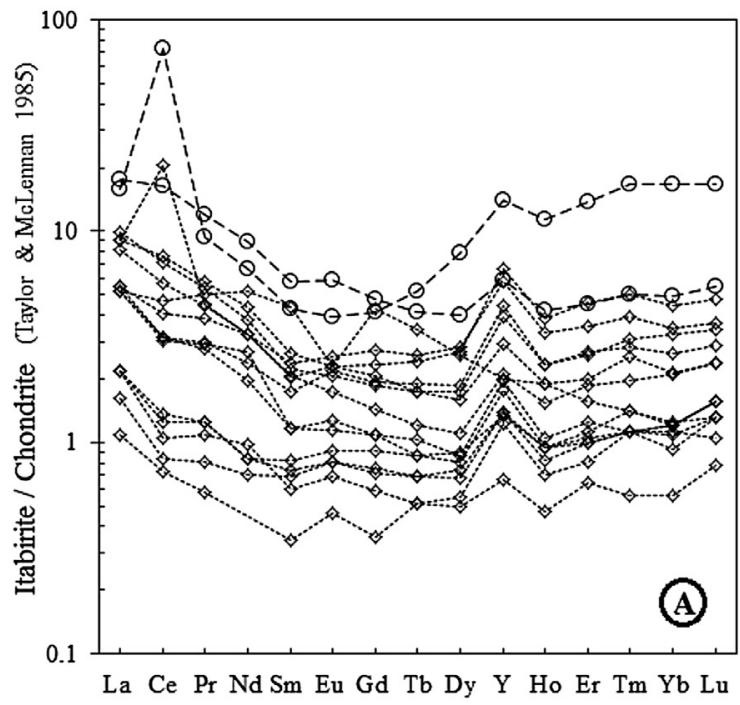

demonstrates that the $\mathrm{Ce} / \mathrm{Ce}^{*}(\mathrm{SN})$ values of the Morro Escuro itabirite are close to 1 with a positive La anomaly, consistent with deposition in an environment of suboxic to anoxic waters (Fig. 13). The values of the $\mathrm{Y}$ anomaly $\left(\mathrm{Y} / \mathrm{Y}^{*}(\mathrm{SN})\right)$ vary between 0.83 and 1.97 and the $\mathrm{Y} / \mathrm{Ho}$ ratio from 26.25 to 47.00 .

Some $\mathrm{Y} / \mathrm{Ho}$ values fall in the chondritic range $(24<\mathrm{Y} / \mathrm{Ho}<34)$ near or inside the "shale" field in the plot $\mathrm{Ce} / \mathrm{Ce}^{*}(\mathrm{SN})$ vs. $\mathrm{Y} / \mathrm{Ho}$ (Fig. 14). It is possible that samples (002-701, 007-701, 009-001), with low Y/Ho (<34), might have been slightly contaminated by clays. The majority of the calculated values, however, are hyperchondritic (Bau et al., 1996) and consistent with an overall absence of fine detritic components, which is also corroborated by the low contents of $\mathrm{Al}_{2} \mathrm{O}_{3} \quad(0.07-1.53 \%), \quad \mathrm{TiO}_{2} \quad(<0.01-0.06 \%), \quad \mathrm{Th}$ $(<0.2-13.7 \mathrm{ppm}), \mathrm{Hf}(<0.1-0.8 \mathrm{ppm}), \mathrm{Sc}(<1-2 \mathrm{ppm})$ in all samples.

\subsection{Similarities with other BIF-sequences}

The REE + Y data from the Morro Escuro itabirite are very similar to the analytical results found in BIFs from the Serro (Appendix D) and Itabira Groups (Spier et al., 2007), with a weak

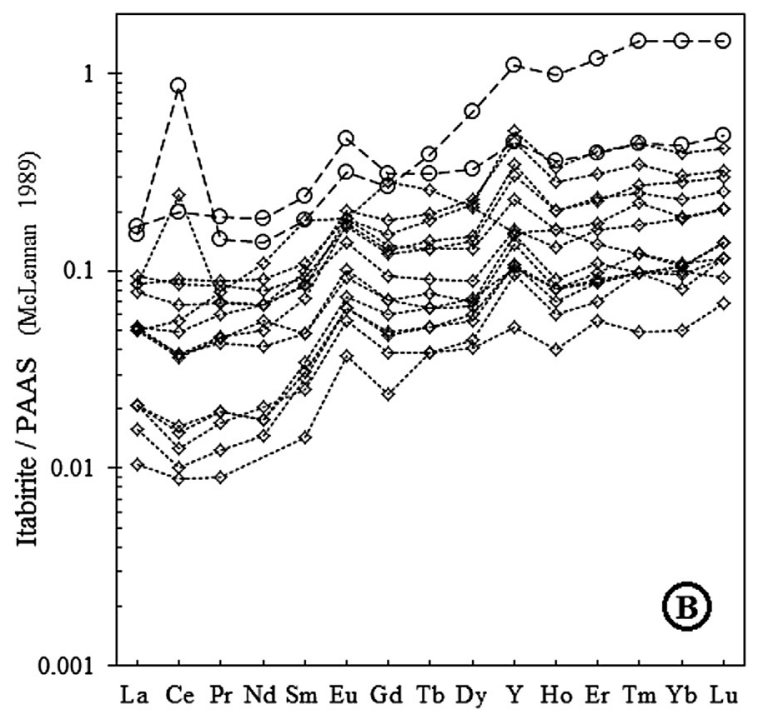

$\cdots-$ BIF without amphibole $\quad-0-$ BIF with amphibole

Fig. 11. Distribution pattern of the REE + Y values of the itabirite from Morro Escuro Ridge normalized to the values of chondrite (A) and PAAS (B). 


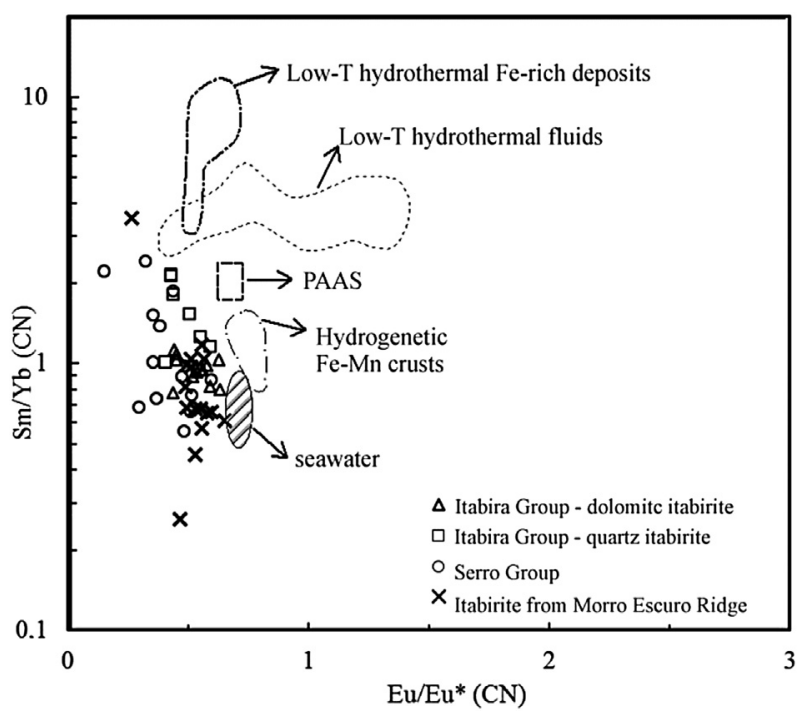

Fig. 12. Diagram of $\mathrm{Eu} / \mathrm{Eu}^{*}{ }_{(\mathrm{CN})}$ vs. $(\mathrm{Sm} / \mathrm{Yb})_{(\mathrm{CN})}$ (Alexander et al., 2008), depicting the distribution of the Morro Escuro itabirite data in relation to the Fe-rich hydrothermal deposits of low T (Puteanus et al., 1991), hydrothermal fluids of low T (Michard et al., 1983), PAAS, hydrogenetic Fe-Mn crusts (Bau et al., 1996), Pacific seawater (Alibo and Nozaki, 1999), Serro Group in the Morro do Pilar region and Itabira Group from the Minas Supergroup (Spier et al., 2007).

positive Eu anomaly, a distinguished positive $\mathrm{Y}$ anomaly and low $(\mathrm{Pr} / \mathrm{Yb})_{(\mathrm{SN})}$ ratios (Table 3 and Fig. 15). These data plot as typical shale-normalized spidergrams similar to most Paleproterozoic BIFs worldwide, such as the late Archean Witwatersrand BIFs, the early Paleoproterozoic Brockman and Kurunam iron formations and the late Paleoproterozoic Lake Superior Biwabik BIF (Table 3 and Fig. 16).

In contrast, the Neoarchean jaspilites from the Carajás Mineral Province and the 3.8 Ga old Isua BIFs (Moorbath et al., 1973) exhibit the highest Eu anomaly and $\Sigma$ REE values (Figueiredo e Silva et al., 2008; Dymek and Klein, 1988). The REE contents of Rapitan-type Neoproterozoic BIFs from the Urucum district (755-730 Ma) are also high, but a positive Eu anomaly is absent (Klein and Ladeira, 2004).

\section{Geochronology}

\section{1. $U-P b$ SHRIMP}

The maximum depositional age for the upper quartzitic unit of the MER sequence was determined according to the youngest detrital zircon grain. Two populations of grains from the

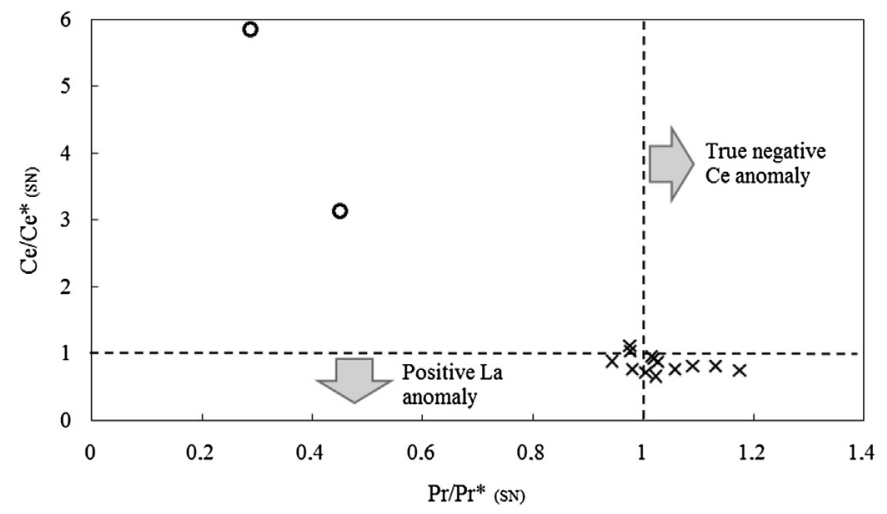

Fig. 13. Discriminative diagram of $\mathrm{Ce} / \mathrm{Ce}^{*}{ }_{(\mathrm{SN})} \mathrm{vs}$. $\operatorname{Pr} / \mathrm{Pr}^{*}{ }_{(\mathrm{SN})}$ for La and $\mathrm{Ce}$ anomalies (Bau and Dulsky, 1996). The circles represent the Ce-allanite bearing samples.

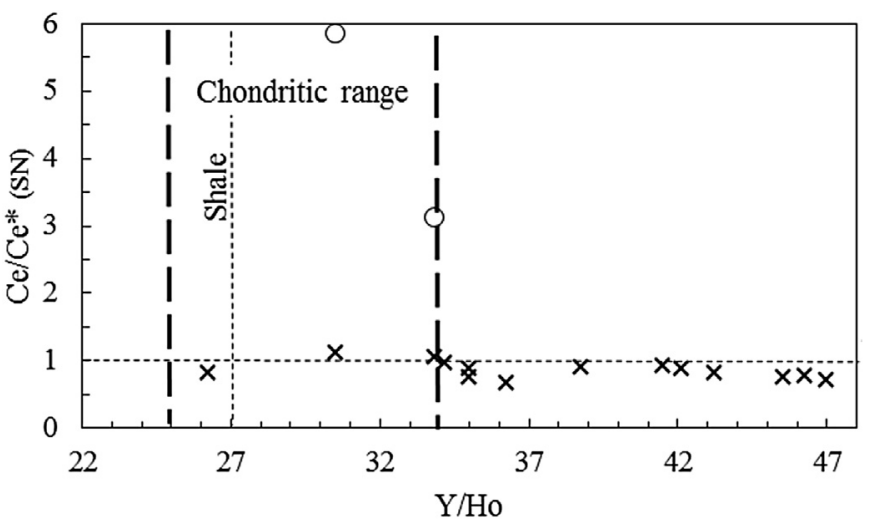

Fig. 14. Ce/Ce* ${ }_{(S N)}$ vs.Y/Ho diagram (Pecoits, 2010). The circles represent the Ce-allanite bearing samples.

metaconglomerate layer and one from the overlying quartzite of the same statigraphic unit (see position on Fig. 3) were investigated and the SHRIMP results delivered three fairly homogeneous histograms. The single values are presented in Appendix E.

In one of the metaconglomerate samples (PTG106), the grains are subrounded to rounded, although some prismatic crystals were also observed, indicating short transport distance from the source. The youngest age found in a population of 30 grains was $1668 \pm 23 \mathrm{Ma}$, which points to a Late Paleoproterozoic (Statherian) maximum sedimentation age. Another younger grain of 1623 Ma was 32\% discordant and had to be excluded. Most of the population is Archean ( $43 \%$ of sample), but with a significant population of Statherian zircon grains (33\% of sample), followed by $23 \%$ Rhyacian grains (Fig. 17A).

Thirty-one analyses were performed on thirty zircon grains in the second conglomerate sample (PTG93) and showed the youngest age of $1753 \pm 32 \mathrm{Ma}$. $43 \%$ of the zircon grains are Archean and $57 \%$ are Paleoproterozoic and the main peak ages are at 1764, 2055, 2145, 2680, 2855, and $3114 \mathrm{Ma}$ (Fig. 17B). One of the grains (e.4 Appendix E) exhibited an alteration halo with very low Th/U ratio (0.005) and an age of $506 \pm 6 \mathrm{Ma}$.

The quartzite sample (PTG226) is comparatively zircon rich with well-rounded grains. Thirty-three crystals were analyzed, with ages varying from $1728 \pm 16 \mathrm{Ma}$ (Statherian) up to $3266 \pm 10 \mathrm{Ma}$ (Paleoarchean - Fig. 17C). The main sources of this quartzite are Archean rocks ( $73 \%$ of the detrital material), with age peaks at 2589 , 2796,2800 , and 2908 Ma. Six zircon grains (18\%) are Rhyacian, with a peak at $2140 \mathrm{Ma}$. Only one grain is Statherian (1728 Ma) and two are Orosirian (1806 Ma and $1967 \mathrm{Ma}$ ).

\section{2. $\mathrm{Sm}-\mathrm{Nd}$}

Geochemical analyses of the orthoamphibolites from the Pedro Lessa Suite (906 Ma; Machado et al., 1989) in the MER indicate tholeiitic basaltic composition with subalkaline to alkaline affinity (Silveira Braga, 2012). The model-ages ( $\mathrm{T}_{\mathrm{DMM}}$ - depleted mantle MORB model) calculated from the $\mathrm{Sm}-\mathrm{Nd}$ isotopic analyses (Table 4 ) of three samples vary from 1.46 to $1.78 \mathrm{Ga}$. The expected model ages would be slightly older than the crystallization age ( $1000 \mathrm{Ma}$ ), considering the juvenile input from the mantlederived basaltic magma. The relatively old $\mathrm{T}_{\mathrm{DMM}}$ model ages in the 1.46-1.78 Ga range, however, suggest that the mantle-derived magma was isotopically contaminated by host rocks along the ascent pathway, particularly in the samples 7-02 and 11-505. Isotopic contamination is a common feature of basaltic magmas (e.g.: Bacon et al., 1994; Paslik et al., 1996; Baker et al., 2000), especially when the upper part of the magma trajectory is dominated by sedimentary rocks, which in the present case would be the units of 
Table 3

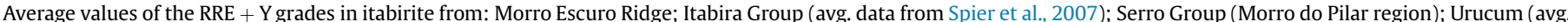

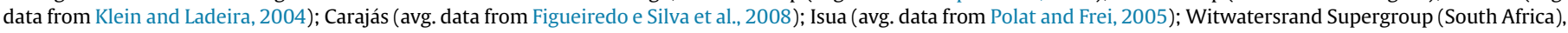

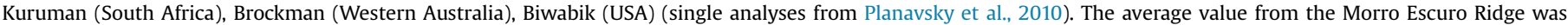
calculated excluding the Ce-allanite- and amphibole-bearing samples (007-701, 008-701, 009-001).

\begin{tabular}{|c|c|c|c|c|c|c|c|c|c|c|c|}
\hline & \multicolumn{6}{|l|}{ Brazilian BIFs } & \multicolumn{5}{|c|}{ Worldwide BIFs } \\
\hline & Morro Escuro & $\begin{array}{l}\text { Itabira group - } \\
\text { quartz itabirite }\end{array}$ & $\begin{array}{l}\text { Itabira group - } \\
\text { dolomite-itabirite }\end{array}$ & Serro group & Uru cum & Carajás & Biwa bik & Brock man & Kuru man & Witwa tersrand & Isua \\
\hline$(\mathrm{Pr} / \mathrm{Yb})_{(\mathrm{SN})}$ & 0.28 & 0.33 & 0.27 & 0.39 & 0.35 & 1.18 & 0.78 & 0.25 & 0.20 & 0.44 & 0.60 \\
\hline $\mathrm{Eu} / \mathrm{Eu}_{(\mathrm{SN})}$ & 1.53 & 1.57 & 1.65 & 1.31 & 1.29 & 3.07 & 1.19 & 1.81 & 1.64 & 1.76 & 3.03 \\
\hline $\mathrm{Ce} / \mathrm{Ce}_{(\mathrm{SN})}$ & 1.14 & 0.81 & 0.82 & 0.99 & 1.65 & 0.74 & 0.89 & 0.80 & 0.78 & 0.86 & 0.91 \\
\hline $\mathrm{Y} / \mathrm{Ho}$ & 39.53 & 35.17 & 37.20 & 41.43 & - & - & 38.30 & 40.14 & 50.74 & 33.13 & 43.99 \\
\hline
\end{tabular}

the Espinhaço Supergroup. The $\varepsilon_{\mathrm{Nd}}(\mathrm{t}=1000)$ values are in the +3.57 and -0.64 range, indicating less contamination of the juvenile mafic magma in sample 5-513 and more contamination in samples 7-02 and 11-505.

The geochemical characteristics and ages are similar to those obtained by Dussin (1994), Silva et al. (1995), Babinski et al. (2005), Gradim et al. (2005) and Martins (2006) for the source magma from the Tonian mafic rocks associated with the rift phase volcanism of the Macaúbas Basin (Dussin, 1994; Noce et al., 1997).

\section{Discussion and conclusions}

The lithostratigraphic units that crop out in the MER inlier comprise metagranitic-gneissic rocks, an itabirite-bearing psammo-pelitic metasedimentary sequence and metaamphibolitic dikes/sills, which underwent low-to intermediategrade metamorphism (Tables 1 and 2). The tectonically intercalated and strongly sheared slices of the Borrachudos Suite granite could be distinguished from the equally common Archean TTG orthogneiss through comparative analyses of our geochemical data with earlier results from both units as delivered by different authors (Dussin, 1994; Fernandes, 2001; Oliveira, 2002) (Figs. 8 and 9).

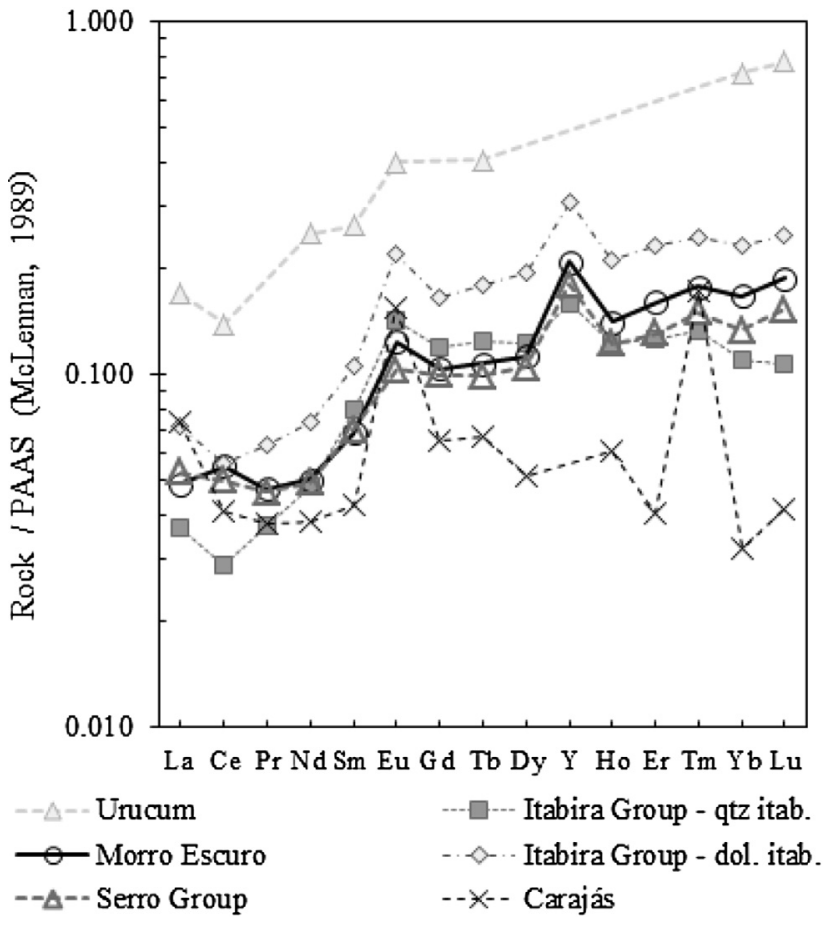

Fig. 15. Average $(\mathrm{REE}+\mathrm{Y})_{\mathrm{SN}}$ spidergrams from Brazilian BIFs: Urucum (Klein and Ladeira, 2004), Serro Group near Morro do Pilar, Cauê Formation of the Itabira Group, Quadrilátero Ferrífero (Spier et al., 2007), Carajás (Figueiredo e Silva et al., 2008).
SHRIMP data of detrital zircon grains of the BIF-related upper quartzitic unit of the MER sequence suggest a maximum upper Statherian age (1668 Ma) for the supracrustal rocks, much younger than the Guanhães Complex (2867 \pm 10 , Silva et al., 2002) as purported by Grossi-Sad et al. (1997), and than the quartzites from the Lower Paleoproterozoic Minas Supergroup. These results also indicate that the psammitic layer is correlatable with the basal units of the Espinhaço Supergroup (Bandeirinha and São João da Chapada Formations) that, according to Chemale Jr. et al. (2012), were deposited between $1800 \mathrm{Ma}$ and $1680 \mathrm{Ma}$. The recurrent main age peaks obtained in the three histograms (Fig. 17) are also in agreement with the evidence of these authors that suggested long periods of intense felsic activity during the Rhyacian and Archean times.

The associated itabirite layer has a relatively simple mineralogical composition with quartz and specularite as oriented plates that usually define a transposition foliation. The psamitic rocks as well as the itabirite have undergone an intense but progressive shear deformation with the generation of rootless intrafolial folds and a pervasive schistosity related to the development of Brasiliano orogenic thrust planes (Pagung de Carvalho et al., 2014). Syn- and post-tectonic blastesis and secondary grain growth of magnetite/

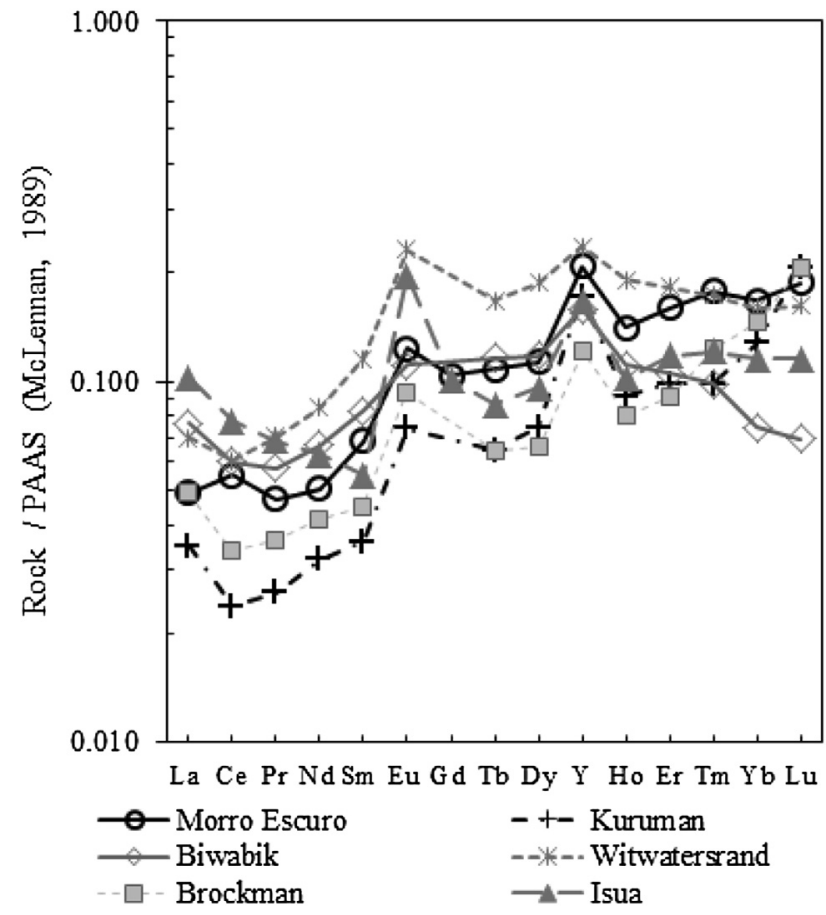

Fig. 16. Comparative plot of Morro Escuro rare earth distribution with $(\mathrm{REE}+\mathrm{Y})_{\mathrm{SN}}$ spidergrams from BIFs worldwide: Isua (avg. data from Polat and Frei, 2005); Witwatersrand Supergroup (South Africa), Kuruman (South Africa), Brockman (Western Australia), Biwabik (USA) (single plots from Planavsky et al., 2010). 

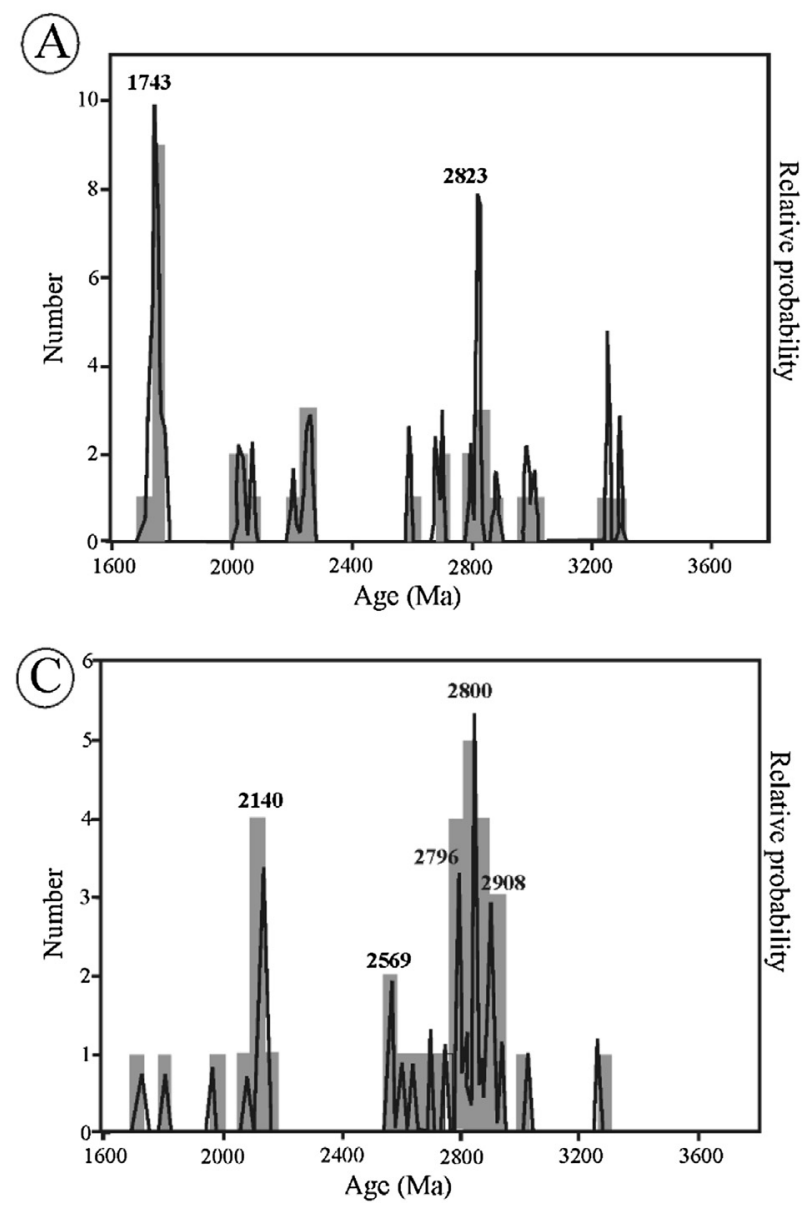

(B)

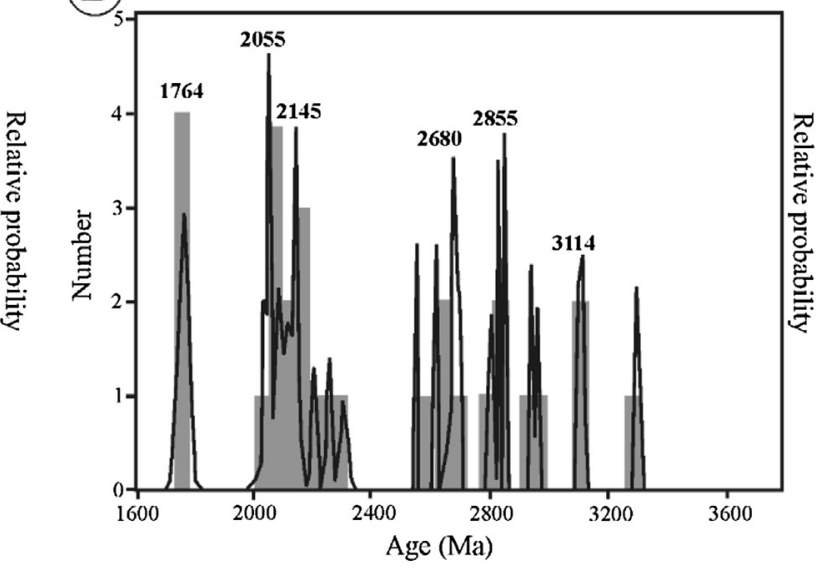

Total $\mathrm{n}=93$

$16.2 \%$ Statherian

$8.6 \%$ Orosirian

$20.4 \%$ Rhyacian

$1.1 \%$ Siderian

$19.4 \%$ Neoarchean

$30.1 \%$ Mesoarchean

$4.3 \%$ Paleoarchean

Fig. 17. Probability diagrams for the ages obtained in zircon grains from the metaconglomerate (A and B) and the quartzite (C).

martite blasts have further contributed to the destruction of primary features of the rocks.

The total obliteration of sedimentary features from all units and the limited geographic extension of the sequence prevent a more definitive conclusion about the basinal environment and stratigraphic position. Nevertheless, the structural characteristics, the compositional and mineralogical homogeneity of the itabirite layer, its association with the Statherian quartzites and metaconglomerates and the lack of extensive carbonate layers supports its correlation with the itabirite from the Serro Group (Grossi-Sad et al., 1997), as described at the Serra da Serpentina and Serra do Sapo ridges and other similar ridges such as those in the Morro do Pilar (Dossin, 1985; Zacchi, 2010; Rolim and Rosière, 2011) and also precludes a correlation with the complex variegated and polydeformed Minas Supergroup.

The geochemical characteristics and the lithologic association of the Morro Escuro itabirites are similar to other Paleoproterozoic sequences (Figs. 15 and 16) deposited in suboxic to anoxic platformal settings (Ce anomaly $\sim 1-$ Table 3 and Appendix C). REE + Y spidergrams from the analyzed samples compose a coherent group (Fig. 11A and $\mathrm{B}$ ) but nonetheless, the wide variation of the values still needs to be elucidated. The low contents of $\mathrm{Al}_{2} \mathrm{O}_{3}, \mathrm{TiO}_{2}, \mathrm{Th}, \mathrm{Hf}$ and Sc and the hypercondritic Y/Ho signature (Fig. 14) indicate a significant absence of terrigenous components and possibly deposition under a shallow marine environment not very distant from the coastline. Pronounced $\mathrm{Eu} / \mathrm{Eu}^{*}(\mathrm{CN})$ is observed in modern marine environments in high temperature $\left(>250{ }^{\circ} \mathrm{C}\right)$ hydrotermal fluids, such as those typically emanating from mid-ocean ridges and back-arc spreading centers (Alexander et al., 2008). The positive but less expressive $\mathrm{Eu}$ anomaly $\left(\mathrm{Eu} / \mathrm{Eu}^{*}(\mathrm{CN})\right)$ and the intermediate to low values of $(\mathrm{Sm} / \mathrm{Yb})_{\mathrm{CN}}$ (Fig. 12) obtained from the Morro Escuro samples indicate the influence of a low temperature hydrothermal input $\left(<200^{\circ} \mathrm{C}\right)$ (Alexander et al., 2008; Danielson et al., 1992; Bau et al., 1996), or, alternatively, a weak contribution of high temperature fluids, due to its distal position with respect to the source vents. The similar and even lower Eu/Eu* ${ }_{(\mathrm{CN})}$ values from the Serro BIFs (Fig. 12) reinforce the correlation of both units, suggesting similar basin conditions or even greater distances of the deposition site from the hydrothermal source.

The alteration halo of zircon overgrowth with a very low Th/U ratio (0.005) of age $506 \pm 6$ Ma observed in one of the detrital zircon grains (e.4 - Appendix E) is caused by syn-metamorphic hydrothermal growth during the Brasiliano orogeny (from 800 to $500 \mathrm{Ma}$ ). This feature is often related to the presence of fluids and sometimes is called "hydrothermal zircon". The local presence of Ce-allanite, responsible for the anomalous positive $\mathrm{Ce} / \mathrm{Ce}^{*}{ }_{(\mathrm{SN})}$ values observed in two itabirite samples, and the relative enrichment of $\mathrm{MgO}$ and

Table 4

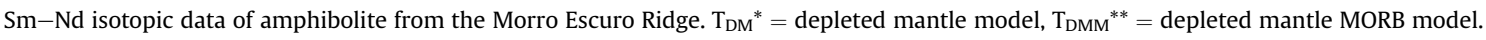

\begin{tabular}{|c|c|c|c|c|c|c|c|}
\hline Sample & Sm (ppm) & $\mathrm{Nd}(\mathrm{ppm})$ & ${ }^{147} \mathrm{Sm} /{ }^{144} \mathrm{Nd}$ & ${ }^{143} \mathrm{Nd} /{ }^{144} \mathrm{Nd}( \pm 2 \mathrm{SE})$ & $\mathrm{T}_{\mathrm{DM}}{ }^{*}(\mathrm{Ga})(\mathrm{t}=1000 \mathrm{Ma})$ & $\mathrm{T}_{\mathrm{DMM}^{* *}}(\mathrm{Ga})(\mathrm{t}=1000 \mathrm{Ma})$ & $\varepsilon \mathrm{Nd}(\mathrm{t}=1000 \mathrm{Ma})$ \\
\hline 7-02 & 5.817 & 25.881 & 0.1359 & $0.512261 \pm 3$ & 1.52 & 1.78 & -0.64 \\
\hline $11-505$ & 11.083 & 54.928 & 0.122 & $0.512175 \pm 2$ & 1.43 & 1.65 & -0.71 \\
\hline $5-513$ & 7.949 & 31.906 & 0.1506 & $0.512564 \pm 3$ & 1.15 & 1.46 & +3.57 \\
\hline
\end{tabular}


alkalis with the formation of Mg-hornblende and tschermakite, also indicate metasomatic alteration. These localized alteration events are probably coeval and suggest the presence of pegmatites and granites during the Brasiliano orogeny (Ribeiro-Althoff et al., 1997; Fernandes et al., 2000; Preinfalk et al., 2002). The alterations are possibly controlled by shear zones but also by the discontinuities along the contact zone of the Early Mesoproterozoic amphibolite dikes that might have contributed elements such as $\mathrm{Mg}$ for the hornblende in the itabirite. Despite the indications of metasomatism and hydrothermal alteration, large, economically important high-grade iron ore bodies ( $>64 \mathrm{wt} \% \mathrm{Fe}$ ) could not be found even after long and intensive detailed prospective campaigns.

The structural and metamorphic transformations of the supracrustal rocks that took place throughout the evolution of the Espinhaço fold and thrust belt may have occurred during different pulses of the Brasiliano orogen. Both supracrustal rocks and basement units were involved in the development of imbricated tectonic slices and obliterated the internal structures. Major crustal thickening related to the stacking of the tectonic slices during successive orogenic pulses resulted in increasing metamorphic grade reaching temperatures which ranged from $512^{\circ}$ to $560{ }^{\circ} \mathrm{C}\left( \pm 50{ }^{\circ} \mathrm{C}\right)$ and a pressure of $5.9 \pm 1 \mathrm{kbar}$ at the base of the MER. Olivo et al. (2011) interpret the wide variety of ages and cooling rates, observed in $\mathrm{Ar}-\mathrm{Ar}$ geochronologic studies in metamorphic biotite, muscovite and hornblende crystals, as the result of a slow and gradual cooling process during erosional events after the tectonic uplift.

\section{Acknowledgments}

The authors would like to express their gratitude to TERRATIVA MINERAIS S.A., represented by Mr. I. G. Wender, which generously contributed to this project's financing, Centaurus Metals, particularly to Dr. K. Petersen, for supplying part of the samples, to the CNPq (Pr. nr. 472602/2009-8.) and FAPEMIG (Pr. Nr. APQ-00557-12) for additional funds. $\mathrm{U}-\mathrm{Pb}$ analyses were performed using a SHRIMP II probe at the John DeLaeter Centre of the Curtin University, Perth Western Australia. We also thank S. Hagemann and an anonymous reviewer for constructive criticism and R. Fuck and J. Kellogg for the editorial handling.

\section{Appendix A. Chemical composition of minerals}

\begin{tabular}{lrrr}
\hline Garnet & & & \\
\hline Sample & $010-133,35$ & $001-106,15$ & $010-501$ \\
\hline wt\% & & & \\
$\mathrm{SiO}_{2}$ & 38.53 & 37.57 & 38.75 \\
$\mathrm{Al}_{2} \mathrm{O}_{3}$ & 20.98 & 21.49 & 21.79 \\
$\mathrm{MgO}$ & 1.95 & 3.86 & 2.91 \\
$\mathrm{CaO}$ & 7.39 & 0.33 & 6.18 \\
$\mathrm{MnO}$ & 1.45 & 0.04 & 1.20 \\
$\mathrm{FeO}$ & 29.22 & 36.39 & 30.69 \\
$\mathrm{Total}$ & 99.52 & 99.67 & 101.51 \\
$\mathrm{Si}$ & 3.07 & 3.01 & 3.03 \\
$\mathrm{Al}$ & -0.07 & -0.01 & -0.03 \\
$\mathrm{Al}$ & 2.04 & 2.04 & 2.03 \\
$\mathrm{Fe}$ & 1.95 & 2.44 & 2.01 \\
$\mathrm{Mg}$ & 0.23 & 0.46 & 0.34 \\
$\mathrm{Mn}$ & 0.10 & 0.00 & 0.08 \\
$\mathrm{Ca}$ & 0.63 & 0.03 & 0.52 \\
$\mathrm{Py}$ & 7.96 & 15.71 & 11.53 \\
$\mathrm{Al}$ & 66.97 & 83.25 & 68.21 \\
$\mathrm{Sp}$ & 3.37 & 0.09 & 2.69 \\
$\mathrm{Gr}$ & 21.70 & 0.96 & 17.58 \\
& & &
\end{tabular}

\begin{tabular}{|c|c|c|c|}
\hline \multicolumn{4}{|c|}{ Plagioclase } \\
\hline Sample & \multicolumn{2}{|c|}{$010-133,35$} & $010-501$ \\
\hline \multicolumn{4}{|l|}{ wt\% } \\
\hline $\mathrm{SiO}_{2}$ & \multicolumn{2}{|c|}{43.90} & 59.61 \\
\hline $\mathrm{Al}_{2} \mathrm{O}_{3}$ & \multicolumn{2}{|c|}{36.36} & 25.98 \\
\hline $\mathrm{FeO}$ & \multicolumn{2}{|c|}{0.02} & 0.12 \\
\hline $\mathrm{CaO}$ & \multicolumn{2}{|c|}{19.52} & 7.73 \\
\hline $\mathrm{Na}_{2} \mathrm{O}$ & \multicolumn{2}{|c|}{0.24} & 6.11 \\
\hline K2O & \multirow{2}{*}{\multicolumn{2}{|c|}{0.00}} & 0.02 \\
\hline Total & 100.04 & & 99.56 \\
\hline $\mathrm{Si}$ & \multicolumn{2}{|c|}{8.11} & 10.63 \\
\hline $\mathrm{Al}$ & \multicolumn{2}{|c|}{7.92} & 5.46 \\
\hline $\mathrm{Fe}$ & \multicolumn{2}{|c|}{0.00} & 0.02 \\
\hline $\mathrm{Ca}$ & & & 1.48 \\
\hline $\mathrm{Na}$ & & & 2.11 \\
\hline $\mathrm{K}$ & & & 0.00 \\
\hline Ano & & & 41.09 \\
\hline $\mathrm{Ab}$ & & & 58.77 \\
\hline Or & & & 0.13 \\
\hline Biotite & & & \\
\hline Sample & $001-106,15$ & 010-501 & $010-133,35$ \\
\hline wt\% & & & \\
\hline $\mathrm{SiO}_{2}$ & 36.78 & 38.99 & 36.85 \\
\hline $\mathrm{TiO}_{2}$ & 1.86 & 1.44 & 2.30 \\
\hline $\mathrm{Al}_{2} \mathrm{O}_{3}$ & 18.49 & 18.54 & 16.27 \\
\hline $\mathrm{FeO}$ & 15.39 & 12.52 & 17.24 \\
\hline MgO & 13.40 & 15.23 & 13.09 \\
\hline $\mathrm{MnO}$ & 0.00 & 0.03 & 0.05 \\
\hline $\mathrm{Na}_{2} \mathrm{O}$ & 0.19 & 0.58 & 0.15 \\
\hline $\mathrm{K}_{2} \mathrm{O}$ & 9.47 & 8.14 & 9.39 \\
\hline $\mathrm{H}_{2} \mathrm{O}^{+}$ & 2.77 & 2.84 & 2.73 \\
\hline Total & 98.35 & 98.48 & 98.08 \\
\hline $\mathrm{Si}$ & 5.37 & 5.56 & 5.45 \\
\hline $\mathrm{Al}_{\text {iv }}$ & 2.63 & 2.44 & 2.55 \\
\hline $\mathrm{Al}_{\mathrm{vi}}$ & 0.55 & 0.68 & 0.29 \\
\hline $\mathrm{Ti}$ & 0.20 & 0.15 & 0.26 \\
\hline $\mathrm{Fe}^{+2}$ & 1.88 & 1.49 & 2.13 \\
\hline Mn & 0.00 & 0.00 & 0.01 \\
\hline Mg & 2.92 & 3.24 & 2.88 \\
\hline $\mathrm{Na}$ & 0.05 & 0.16 & 0.04 \\
\hline K & 1.76 & 1.48 & 1.77 \\
\hline $\mathrm{H}_{2} \mathrm{O}$ & 2.70 & 2.70 & 2.70 \\
\hline$\% \mathrm{H}_{2} \mathrm{O}$ & 2.77 & 2.84 & 2.73 \\
\hline Amphibc & & & \\
\hline Sample & & & $010-133,35$ \\
\hline wt\% & & & \\
\hline $\mathrm{SiO}_{2}$ & & & 47.35 \\
\hline $\mathrm{TiO}_{2}$ & & & 0.30 \\
\hline $\mathrm{Al}_{2} \mathrm{O}_{3}$ & & & 9.90 \\
\hline $\mathrm{FeO}$ & & & 12.83 \\
\hline $\mathrm{MgO}$ & & & 13.58 \\
\hline $\mathrm{MnO}$ & & & 0.26 \\
\hline $\mathrm{CaO}$ & & & 11.49 \\
\hline $\mathrm{Na}_{2} \mathrm{O}$ & & & 0.48 \\
\hline $\mathrm{K}_{2} \mathrm{O}$ & & & 0.31 \\
\hline $\mathrm{H}_{2} \mathrm{O}^{+}$ & & & 2.11 \\
\hline Total & & & 98.59 \\
\hline $\mathrm{Si}$ & & & 6.73 \\
\hline $\mathrm{Al}$ & & & 1.66 \\
\hline $\mathrm{Ti}$ & & & 0.03 \\
\hline $\mathrm{Fe}^{+2}$ & & & 1.53 \\
\hline $\mathrm{Mg}$ & & & 2.88 \\
\hline $\mathrm{Mn}$ & & & 0.03 \\
\hline $\mathrm{Ca}$ & & & 1.75 \\
\hline $\mathrm{Na}$ & & & 0.13 \\
\hline K & & & 0.06 \\
\hline $\mathrm{OH}$ & & & 2.00 \\
\hline$\% \mathrm{H}_{2} \mathrm{O}$ & & & 2.11 \\
\hline
\end{tabular}




\section{Appendix B. Chemical composition of the granite and gneiss}

\begin{tabular}{|c|c|c|c|c|c|c|c|c|c|c|c|}
\hline Sample & Detection limit & 006-501 & 018-003 & $172-001$ & 048-004 & $179-001$ & 060 & 011-001 & $007-501$ & 036-003 & $177-002$ \\
\hline wt\% & $\%$ & & & & & & & & & & \\
\hline $\mathrm{SiO}_{2}$ & 0.01 & 74.87 & 87.03 & 75.61 & 72.15 & 74.48 & 74.44 & 72.75 & 71.82 & 71.58 & 72.06 \\
\hline $\mathrm{Al}_{2} \mathrm{O}_{3}$ & 0.01 & 11.93 & 7.12 & 13.13 & 14.77 & 13 & 13.67 & 14.47 & 14.98 & 13.4 & 14.48 \\
\hline $\mathrm{Fe}_{2} \mathrm{O}_{3}$ & 0.01 & 2.2 & 1.09 & 2.31 & 1.83 & 2.29 & 1.34 & 1.35 & 2.02 & 3.26 & 2.12 \\
\hline $\mathrm{MgO}$ & 0.01 & 0.54 & 0.24 & 0.19 & 0.5 & 0.34 & 0.27 & 0.3 & 0.88 & 0.42 & 0.57 \\
\hline $\mathrm{CaO}$ & 0.01 & 0.71 & 0.04 & 2.32 & 1.74 & 0.96 & 0.92 & 1.1 & 0.94 & 2.06 & 2.18 \\
\hline $\mathrm{Na}_{2} \mathrm{O}$ & 0.01 & 1.84 & 0.28 & 3.84 & 4.47 & 2.98 & 3.59 & 4.44 & 3.24 & 2.27 & 4.48 \\
\hline $\mathrm{K}_{2} \mathrm{O}$ & 0.01 & 6.57 & 3.15 & 1.86 & 3.39 & 4.77 & 5.12 & 3.94 & 4.76 & 5.6 & 2.18 \\
\hline $\mathrm{TiO}_{2}$ & 0.01 & 0.22 & 0.1 & 0.24 & 0.25 & 0.24 & 0.15 & 0.19 & 0.23 & 0.38 & 0.24 \\
\hline $\mathrm{P}_{2} \mathrm{O}_{5}$ & 0.01 & 0.02 & 0.04 & 0.05 & 0.07 & 0.06 & 0.06 & 0.05 & 0.07 & 0.1 & 0.08 \\
\hline $\mathrm{MnO}$ & 0.01 & 0.04 & 0.02 & 0.03 & 0.02 & 0.04 & 0.03 & 0.03 & 0.03 & 0.04 & 0.02 \\
\hline $\mathrm{Cr}_{2} \mathrm{O}_{3}$ & 0.002 & bdl & bdl & bdl & bdl & bdl & bdl & bdl & bdl & bdl & bdl \\
\hline LOI & -5.1 & 0.9 & 0.8 & 0.2 & 0.6 & 0.7 & 0.3 & 1.2 & 0.9 & 0.5 & 1.5 \\
\hline Sum & & 99.84 & 99.93 & 99.77 & 99.77 & 99.8 & 99.86 & 99.77 & 99.85 & 99.6 & 99.86 \\
\hline \multicolumn{12}{|l|}{ ppm } \\
\hline $\mathrm{Rb}$ & 0.1 & 287.4 & 161.5 & 43.9 & 78.5 & 164.8 & 231.6 & 116.7 & 125.2 & 192.3 & 70.5 \\
\hline $\mathrm{Nb}$ & 0.1 & 35.5 & 9.7 & 26.9 & 3.3 & 6.4 & 10.5 & 7 & 5 & 31.1 & 3.3 \\
\hline $\mathrm{Y}$ & 0.1 & 84 & 102 & 95.2 & 5.4 & 13.3 & 27.1 & 9.7 & 8.3 & 139 & 5 \\
\hline La & 0.1 & 110.9 & 59 & 82.3 & 75.9 & 78.9 & 36.8 & 49.3 & 11.8 & 227.1 & 27.4 \\
\hline $\mathrm{Ce}$ & 0.1 & 233.7 & 50.8 & 234.8 & 141.5 & 133.1 & 73.9 & 96.2 & 22.1 & 470.8 & 50.5 \\
\hline $\operatorname{Pr}$ & 0.02 & 23.7 & 20.43 & 19.42 & 12.75 & 14.16 & 7.66 & 9.28 & 2.29 & 49.4 & 4.9 \\
\hline $\mathrm{Nd}$ & 0.3 & 85.5 & 79.2 & 70.9 & 39.1 & 45.4 & 24.5 & 29.3 & 8 & 176.9 & 15.9 \\
\hline $\mathrm{Sm}$ & 0.05 & 16.01 & 17.99 & 13.97 & 4.73 & 6.4 & 4.55 & 4.23 & 1.54 & 31.35 & 2.29 \\
\hline $\mathrm{Eu}$ & 0.02 & 0.68 & 2.82 & 2.22 & 0.89 & 1.13 & 0.48 & 0.87 & 0.36 & 2.89 & 0.65 \\
\hline $\mathrm{Gd}$ & 0.05 & 15.18 & 18.02 & 13.78 & 2.62 & 4.18 & 4.23 & 2.62 & 1.37 & 28.28 & 1.6 \\
\hline $\mathrm{Tb}$ & 0.01 & 2.54 & 3.31 & 2.65 & 0.29 & 0.53 & 0.75 & 0.36 & 0.24 & 4.6 & 0.22 \\
\hline Dy & 0.05 & 14.46 & 18.89 & 16 & 1.11 & 2.44 & 4.29 & 1.84 & 1.25 & 26.08 & 1.02 \\
\hline Ho & 0.02 & 2.98 & 3.58 & 3.47 & 0.18 & 0.44 & 0.89 & 0.3 & 0.24 & 5.2 & 0.17 \\
\hline $\mathrm{Er}$ & 0.03 & 8.38 & 9.71 & 10.15 & 0.44 & 1.16 & 2.63 & 0.77 & 0.75 & 13.44 & 0.43 \\
\hline $\mathrm{Tm}$ & 0.01 & 1.22 & 1.41 & 1.44 & 0.07 & 0.18 & 0.4 & 0.12 & 0.13 & 1.85 & 0.06 \\
\hline $\mathrm{Yb}$ & 0.05 & 7.7 & 8.89 & 8.69 & 0.34 & 1.15 & 2.55 & 0.69 & 0.76 & 10.77 & 0.38 \\
\hline Lu & 0.01 & 1.15 & 1.2 & 1.29 & 0.07 & 0.2 & 0.4 & 0.1 & 0.13 & 1.45 & 0.06 \\
\hline$\sum E T R$ & & 524.10 & 295.25 & 481.08 & 279.99 & 289.37 & 164.03 & 195.98 & 50.96 & 1050.11 & 105.58 \\
\hline${ }^{\mathrm{a}} \mathrm{La} / \mathrm{Yb}_{(\mathrm{CN})}$ & & 9.73 & 4.48 & 6.40 & 150.85 & 46.36 & 9.75 & 48.28 & 10.49 & 14.25 & 48.73 \\
\hline${ }^{\mathrm{b}} \mathrm{Eu} / \mathrm{Eu}^{*}{ }_{(\mathrm{CN})}$ & & 0.07 & 0.24 & 0.24 & 0.35 & 0.31 & 0.16 & 0.37 & 0.37 & 0.15 & 0.49 \\
\hline
\end{tabular}

Notes.

bdl - below detection limit

${ }^{a}$ Chondrite normalization based on Evensen et al. (1978).

${ }^{\mathrm{b}} \mathrm{Eu} / \mathrm{Eu}^{*}{ }_{(\mathrm{CN})}=\mathrm{Eu}_{(\mathrm{CN})} / \mathrm{Sm}_{(\mathrm{CN})}+\mathrm{Gd}_{(\mathrm{CN})}$. 
Appendix C. Chemical composition of the itabirite from Morro Escuro Ridge.

\begin{tabular}{|c|c|c|c|c|c|c|c|c|c|c|c|c|c|c|c|c|c|}
\hline Sample & $\begin{array}{l}\text { Detection } \\
\text { limit }\end{array}$ & $\begin{array}{l}001- \\
701\end{array}$ & $\begin{array}{l}002- \\
701\end{array}$ & $\begin{array}{l}003- \\
701\end{array}$ & $\begin{array}{l}004- \\
701\end{array}$ & $\begin{array}{l}005- \\
701\end{array}$ & $\begin{array}{l}006- \\
701\end{array}$ & $\begin{array}{l}007- \\
701\end{array}$ & $\begin{array}{l}008- \\
701\end{array}$ & $\begin{array}{l}010- \\
701\end{array}$ & $\begin{array}{l}011- \\
701\end{array}$ & $\begin{array}{l}013- \\
701\end{array}$ & $\begin{array}{l}\text { 014- } \\
701\end{array}$ & $\begin{array}{l}015- \\
701\end{array}$ & $\begin{array}{l}002- \\
001\end{array}$ & $\begin{array}{l}009- \\
001\end{array}$ & $\begin{array}{l}013- \\
001\end{array}$ \\
\hline wt\% & $\%$ & & & & & & & & & & & & & & & & \\
\hline $\mathrm{SiO}_{2}$ & 0.01 & 48.13 & 50.7 & 51.38 & 52.93 & 50.43 & 60.25 & 59.28 & 67.83 & 47.9 & 61.06 & 52.71 & 50.04 & 52.46 & 53.62 & 52.43 & 59.07 \\
\hline $\mathrm{Al}_{2} \mathrm{O}_{3}$ & 0.01 & 0.08 & 0.1 & 0.07 & 0.16 & 0.08 & 0.17 & 0.26 & 1.53 & 0.09 & 0.22 & 0.17 & 0.09 & 0.07 & 0.31 & 0.36 & 0.22 \\
\hline $\mathrm{Fe}_{2} \mathrm{O}_{3}$ & 0.01 & 51.39 & 48.51 & 48.32 & 45.47 & 48.99 & 37.97 & 39.17 & 28.52 & 51.47 & 38.17 & 46.63 & 49.78 & 47.09 & 44.37 & 44.29 & 40.13 \\
\hline $\mathrm{MgO}$ & 0.01 & bdl & bdl & bdl & bdl & bdl & bdl & bdl & 0.74 & bdl & bdl & bdl & bdl & bdl & 0.04 & 0.25 & bdl \\
\hline $\mathrm{CaO}$ & 0.01 & 0.02 & bdl & 0.09 & 0.34 & 0.1 & 0.02 & 0.1 & 0.38 & 0.09 & bdl & 0.13 & 0.06 & 0.03 & 0.99 & 0.82 & 0.04 \\
\hline $\mathrm{Na}_{2} \mathrm{O}$ & 0.01 & bdl & bdl & bdl & bdl & bdl & bdl & bdl & 0.2 & bdl & bdl & bdl & bdl & bdl & 0.02 & 0.06 & bdl \\
\hline $\mathrm{K}_{2} \mathrm{O}$ & 0.01 & bdl & 0.01 & bdl & bdl & bdl & 0.02 & 0.02 & 0.4 & bdl & bdl & bdl & bdl & bdl & 0.02 & 0.02 & 0.04 \\
\hline $\mathrm{TiO}_{2}$ & 0.01 & bdl & bdl & bdl & 0.01 & bdl & $<0.01$ & 0.01 & 0.06 & bdl & 0.01 & 0.01 & bdl & bdl & 0.04 & 0.03 & 0.02 \\
\hline $\mathrm{P}_{2} \mathrm{O}_{5}$ & 0.01 & 0.06 & 0.05 & 0.04 & 0.27 & 0.09 & bdl & 0.11 & 0.14 & 0.07 & 0.04 & 0.12 & 0.07 & 0.04 & 0.71 & 0.49 & 0.04 \\
\hline $\mathrm{MnO}$ & 0.01 & 0.06 & 0.03 & 0.07 & 0.03 & bdl & 0.03 & 0.01 & 0.18 & 0.08 & 0.03 & 0.02 & 0.04 & 0.01 & 0.07 & 0.06 & 0.04 \\
\hline $\mathrm{Cr}_{2} \mathrm{O}_{3}$ & 0.002 & bdl & bdl & bdl & bdl & bdl & bdl & bdl & bdl & bdl & bdl & bdl & bdl & 0.003 & bdl & bdl & 0.002 \\
\hline LOI & -5.1 & 0.2 & 0.6 & 0 & 0.8 & 0.3 & 1.5 & 1.1 & 0 & 0.3 & 0.5 & 0.2 & -0.1 & 0.3 & -0.2 & 1.2 & 0.4 \\
\hline Sum & & 99.94 & 99.99 & 99.99 & 100.01 & 100.01 & 100.01 & 100.01 & 99.99 & 100.00 & 100.01 & 100.00 & 100.00 & 100.00 & 100.00 & 99.97 & 100.01 \\
\hline ppm & ppm & & & & & & & & & & & & & & & & \\
\hline $\mathrm{Hf}$ & 0.1 & 0.1 & bdl & bdl & 0.1 & 0.1 & $<0.1$ & 0.1 & 0.8 & bdl & 0.2 & bdl & bdl & bdl & 0.2 & 0.3 & 0.2 \\
\hline Th & 0.2 & bdl & bdl & bdl & 0.3 & $<0.2$ & $<0.2$ & 2.9 & 1.6 & bdl & 0.3 & bdl & bdl & bdl & 0.6 & 13.7 & 0.7 \\
\hline Sc & 1 & bdl & bdl & bdl & bdl & bdl & bdl & 1 & 2 & bdl & 1 & bdl & bdl & bdl & bdl & 1 & 2 \\
\hline $\mathrm{Y}$ & 0.1 & 2.9 & 4.2 & 2.6 & 12.1 & 4.1 & 2.8 & 4.4 & 12.3 & 3.7 & 13.9 & 9.4 & 2.9 & 1.4 & 8.3 & 29.6 & 6.2 \\
\hline $\mathrm{La}$ & 0.1 & 0.8 & 1.9 & 0.8 & 2 & 1.9 & 1.9 & 3.3 & 6.4 & 0.8 & 3 & 2 & 0.6 & 0.4 & 3.3 & 5.8 & 3.6 \\
\hline $\mathrm{Ce}$ & 0.1 & 1.2 & 4.5 & 1 & 3.9 & 2.9 & 3 & 19.5 & 15.7 & 1.3 & 5.4 & 3 & 0.8 & 0.7 & 7.3 & 69.5 & 6.8 \\
\hline $\operatorname{Pr}$ & 0.02 & 0.17 & 0.69 & 0.15 & 0.53 & 0.4 & 0.38 & 0.62 & 1.65 & 0.17 & 0.61 & 0.41 & 0.11 & 0.08 & 0.79 & 1.29 & 0.74 \\
\hline $\mathrm{Nd}$ & 0.3 & 0.6 & 3.7 & 0.7 & 2.3 & 1.9 & 1.4 & 2.3 & 6.3 & 0.6 & 2.3 & 1.7 & 0.5 & bdl & 3.1 & 4.7 & 2.7 \\
\hline $\mathrm{Sm}$ & 0.05 & 0.17 & 1.01 & 0.14 & 0.55 & 0.27 & 0.27 & 0.48 & 1.34 & 0.19 & 0.47 & 0.4 & 0.16 & 0.08 & 0.61 & 1 & 0.51 \\
\hline $\mathrm{Eu}$ & 0.02 & 0.07 & 0.2 & 0.06 & 0.22 & 0.1 & 0.11 & 0.15 & 0.51 & 0.08 & 0.2 & 0.19 & 0.07 & 0.04 & 0.2 & 0.34 & 0.18 \\
\hline $\mathrm{Gd}$ & 0.05 & 0.22 & 1.31 & 0.18 & 0.84 & 0.33 & 0.33 & 0.44 & 1.46 & 0.28 & 0.71 & 0.59 & 0.23 & 0.11 & 0.63 & 1.26 & 0.57 \\
\hline $\mathrm{Tb}$ & 0.01 & 0.04 & 0.2 & 0.03 & 0.15 & 0.06 & 0.05 & 0.07 & 0.24 & 0.05 & 0.14 & 0.11 & 0.04 & 0.03 & 0.1 & 0.3 & 0.1 \\
\hline Dy & 0.05 & 0.28 & 0.99 & 0.21 & 1.08 & 0.33 & 0.34 & 0.42 & 1.53 & 0.31 & 1.02 & 0.71 & 0.26 & 0.19 & 0.66 & 3.03 & 0.61 \\
\hline Ho & 0.02 & 0.08 & 0.16 & 0.06 & 0.28 & 0.09 & 0.08 & 0.13 & 0.36 & 0.08 & 0.33 & 0.2 & 0.07 & 0.04 & 0.2 & 0.97 & 0.16 \\
\hline $\mathrm{Er}$ & 0.03 & 0.25 & 0.39 & 0.2 & 0.88 & 0.31 & 0.26 & 0.46 & 1.12 & 0.28 & 1.14 & 0.67 & 0.25 & 0.16 & 0.64 & 3.42 & 0.5 \\
\hline $\mathrm{Tm}$ & 0.01 & 0.04 & 0.05 & 0.04 & 0.14 & 0.04 & 0.04 & 0.07 & 0.18 & 0.05 & 0.18 & 0.1 & 0.04 & 0.02 & 0.11 & 0.59 & 0.09 \\
\hline $\mathrm{Yb}$ & 0.05 & 0.27 & 0.31 & 0.23 & 0.86 & 0.3 & 0.28 & 0.52 & 1.23 & 0.3 & 1.11 & 0.65 & 0.3 & 0.14 & 0.8 & 4.1 & 0.53 \\
\hline $\mathrm{Lu}$ & 0.01 & 0.05 & 0.05 & 0.05 & 0.14 & 0.06 & 0.04 & 0.09 & 0.21 & 0.06 & 0.18 & 0.11 & 0.06 & 0.03 & 0.13 & 0.63 & 0.09 \\
\hline$\sum E T R$ & & 4.24 & 15.46 & 3.85 & 13.87 & 8.99 & 8.48 & 28.55 & 38.23 & 4.55 & 16.79 & 10.84 & 3.49 & 2.02 & 26.87 & 126.53 & 23.38 \\
\hline${ }^{a} \mathrm{Pr} / \mathrm{Yb}_{(\mathrm{SN})}$ & & 0.20 & 0.71 & 0.21 & 0.20 & 0.43 & 0.43 & 0.38 & 0.43 & 0.18 & 0.18 & 0.20 & 0.12 & 0.18 & 0.32 & 0.10 & 0.45 \\
\hline${ }^{\mathrm{b}} \mathrm{Eu} / \mathrm{Eu}^{*}(\mathrm{SN})$ & & 1.74 & 0.90 & 1.89 & 1.57 & 1.61 & 1.91 & 1.60 & 1.80 & 1.69 & 1.60 & 1.86 & 1.80 & 1.66 & 1.61 & 1.28 & 1.61 \\
\hline${ }^{\mathrm{c}} \mathrm{Ce} / \mathrm{Ce}^{*}{ }_{(\mathrm{SN})}$ & & 0.75 & 0.88 & 0.66 & 0.87 & 0.77 & 0.81 & 3.13 & 1.11 & 0.81 & 0.92 & 0.76 & 0.71 & 0.90 & 1.04 & 5.86 & 0.96 \\
\hline${ }^{\mathrm{d}} \mathrm{Y} / \mathrm{Y}^{*}{ }_{(\mathrm{SN})}$ & & 1.53 & 0.83 & 1.83 & 1.75 & 1.88 & 1.35 & 1.48 & 1.32 & 1.86 & 1.87 & 1.97 & 1.70 & 1.28 & 1.79 & 1.35 & 1.57 \\
\hline $\mathrm{Y} / \mathrm{Ho}$ & & 36.25 & 26.25 & 43.33 & 43.21 & 45.56 & 35.00 & 33.85 & 34.17 & 46.25 & 42.12 & 47.00 & 41.43 & 35.00 & 41.50 & 30.52 & 38.75 \\
\hline${ }^{e} \mathrm{Pr} / \mathrm{Yb}_{(\mathrm{CN})}$ & & 1.14 & 4.03 & 1.18 & 1.12 & 2.41 & 2.46 & 2.16 & 2.43 & 1.03 & 0.99 & 1.14 & 0.66 & 1.03 & 1.79 & 0.57 & 2.53 \\
\hline${ }^{\mathrm{f}} \mathrm{Eu} / \mathrm{Eu}^{*}{ }_{(\mathrm{CN})}$ & & 0.55 & 0.27 & 0.58 & 0.49 & 0.51 & 0.56 & 0.49 & 0.55 & 0.53 & 0.53 & 0.60 & 0.56 & 0.65 & 0.49 & 0.46 & 0.51 \\
\hline${ }^{\mathrm{g}} \mathrm{Ce} / \mathrm{Ce}^{*}{ }_{(\mathrm{CN})}$ & & 0.37 & 0.46 & 0.32 & 0.44 & 0.37 & 0.39 & 1.51 & 0.56 & 0.40 & 0.45 & 0.37 & 0.34 & 0.44 & 0.52 & 2.88 & 0.47 \\
\hline
\end{tabular}

Notes

The negative sign of the loss on ignition (LOI) value indicates that there were no volatiles in the sample.

a b c dPAAS normalization values based on McLennan (1989).

e f ${ }^{2}$ Chondrite normalization based on Taylor and McLennan (1985).

${ }^{\mathrm{b}} \mathrm{Eu} / \mathrm{Eu}^{*}{ }_{(\mathrm{SN})}=\mathrm{Eu}_{(\mathrm{SN})} / 0.66 \mathrm{Sm}_{(\mathrm{SN})}+0.33 \mathrm{~Tb}_{(\mathrm{SN})}$.

${ }^{\mathrm{c}} \mathrm{Ce} / \mathrm{Ce}^{*}{ }_{(\mathrm{SN})}=\mathrm{Ce}_{(\mathrm{SN})} / 0.5 \mathrm{La}_{(\mathrm{SN})}+0.5 \mathrm{Pr}_{(\mathrm{SN})}$.

${ }^{\mathrm{d}} \mathrm{Y} / \mathrm{Y}^{*}{ }_{(\mathrm{SN})}=\mathrm{Y}_{(\mathrm{SN})} / 0.5 \mathrm{Dy}_{(\mathrm{SN})}+0.5 \mathrm{Ho}_{(\mathrm{SN})} \cdot{ }^{\mathrm{f}} \mathrm{Eu} / \mathrm{Eu}^{*}{ }_{(\mathrm{CN})}=\mathrm{Eu}_{(\mathrm{CN})} / \mathrm{Sm}_{(\mathrm{CN})}+\mathrm{Gd}_{(\mathrm{CN})}$.

${ }^{\mathrm{g}} \mathrm{Ce} / \mathrm{Ce}^{*}{ }_{(\mathrm{CN})}=\mathrm{Ce}_{(\mathrm{CN})} / \mathrm{La}_{(\mathrm{CN})}+\operatorname{Pr}_{(\mathrm{CN})}$

bdl - below detection limit. 
Appendix D. Chemical composition of the itabirite from Morro do Pilar region

\begin{tabular}{|c|c|c|c|c|c|c|c|c|c|c|c|c|c|c|}
\hline Sample & Detection limit & 006-502 & 011-502 & 013-503 & 014-503 & 016-502 & 016-504 & 016-505 & 017-505 & 018-503 & 019-502 & $023-503$ & 024-502 & 012-502 \\
\hline wt\% & $\%$ & & & & & & & & & & & & & \\
\hline $\mathrm{SiO}_{2}$ & 0.01 & 49.48 & 51.36 & 54.87 & 49.27 & 53.24 & 45.41 & 56.14 & 52.68 & 54.73 & 70.38 & 50.39 & 55.81 & 53.34 \\
\hline $\mathrm{Al}_{2} \mathrm{O}_{3}$ & 0.01 & 0.13 & 0.11 & 0.24 & 0.29 & 0.33 & 0.13 & 0.15 & 0.39 & 0.16 & 0.68 & 1.88 & 1.52 & 0.11 \\
\hline $\mathrm{Fe}_{2} \mathrm{O}_{3}$ & 0.01 & 50.03 & 48.12 & 44.11 & 49.79 & 45.32 & 54.10 & 43.16 & 46.24 & 44.64 & 27.97 & 43.73 & 41.49 & 46.36 \\
\hline $\mathrm{MgO}$ & 0.01 & bdl & 0.04 & bdl & 0.06 & bdl & bdl & bdl & 0.12 & bdl & 0.02 & 1.23 & 0.07 & bdl \\
\hline $\mathrm{CaO}$ & 0.01 & bdl & 0.03 & bdl & 0.02 & bdl & bdl & 0.04 & 0.02 & bdl & 0.01 & 0.41 & bdl & bdl \\
\hline $\mathrm{Na}_{2} \mathrm{O}$ & 0.01 & bdl & bdl & bdl & bdl & bdl & bdl & bdl & bdl & bdl & bdl & bdl & 0.02 & bdl \\
\hline $\mathrm{K}_{2} \mathrm{O}$ & 0.01 & 0.01 & bdl & 0.05 & 0.05 & 0.03 & bdl & 0.02 & 0.06 & bdl & 0.10 & 0.21 & 0.44 & bdl \\
\hline $\mathrm{TiO}_{2}$ & 0.01 & bdl & bdl & bdl & 0.02 & 0.01 & bdl & bdl & 0.03 & bdl & 0.03 & 0.07 & 0.07 & bdl \\
\hline $\mathrm{P}_{2} \mathrm{O}_{5}$ & 0.01 & 0.03 & 0.04 & 0.03 & 0.02 & 0.02 & 0.03 & 0.05 & 0.02 & 0.02 & 0.02 & 0.07 & 0.03 & 0.03 \\
\hline $\mathrm{MnO}$ & 0.01 & 0.06 & 0.06 & 0.03 & 0.05 & 0.02 & 0.02 & 0.10 & 0.04 & 0.02 & 0.32 & 0.67 & 0.05 & 0.02 \\
\hline $\mathrm{Cr}_{2} \mathrm{O}_{3}$ & 0.002 & bdl & bdl & 0.002 & 0.003 & 0.002 & bdl & 0.003 & bdl & bdl & bdl & 0.007 & bdl & 0.004 \\
\hline LOI & -5.1 & 0.2 & 0.2 & 0.6 & 0.4 & 1.0 & 0.3 & 0.3 & 0.4 & 0.4 & 0.4 & 1.3 & 0.4 & 0.1 \\
\hline Sum & & 99.94 & 99.96 & 99.93 & 99.97 & 99.97 & 99.99 & 99.96 & 100.00 & 99.97 & 99.93 & 99.97 & 99.90 & 99.96 \\
\hline ppm & ppm & & & & & & & & & & & & & \\
\hline $\mathrm{Hf}$ & 0.1 & 0.4 & 0.2 & 0.1 & bdl & 0.1 & bdl & 0.2 & 0.7 & bdl & 0.5 & 0.8 & 0.7 & 0.2 \\
\hline Th & 0.2 & 0.3 & bdl & 0.3 & 0.4 & 0.3 & bdl & bdl & 1.1 & 0.2 & 0.7 & 2.1 & 2.4 & 0.3 \\
\hline Sc & 1 & bdl & bdl & bdl & bdl & bdl & bdl & bdl & bdl & bdl & 1 & 2 & 1 & bdl \\
\hline $\mathrm{Y}$ & 0.1 & 4.4 & 3.8 & 2.5 & 4.6 & 1.3 & 2.8 & 7.3 & 3.9 & 2.1 & 7.2 & 10.6 & 3.4 & 9.5 \\
\hline $\mathrm{La}$ & 0.1 & 1.0 & 0.8 & 2.1 & 3.8 & 1.1 & 0.4 & 1.1 & 2.7 & 1.7 & 2.6 & 3.9 & 3.4 & 1.7 \\
\hline $\mathrm{Ce}$ & 0.1 & 1.5 & 1.2 & 3.5 & 5.8 & 1.6 & 0.5 & 1.8 & 5.8 & 7.5 & 5.1 & 8.5 & 6.3 & 2.6 \\
\hline $\operatorname{Pr}$ & 0.02 & 0.20 & 0.15 & 0.41 & 0.67 & 0.14 & 0.07 & 0.27 & 0.64 & 0.29 & 0.58 & 0.95 & 0.63 & 0.33 \\
\hline $\mathrm{Nd}$ & 0.3 & 0.8 & 0.7 & 1.9 & 2.9 & 0.5 & 0.4 & 1.4 & 2.5 & 1.1 & 2.5 & 3.7 & 1.9 & 1.5 \\
\hline $\mathrm{Sm}$ & 0.05 & 0.20 & 0.15 & 0.45 & 0.61 & 0.10 & 0.11 & 0.45 & 0.41 & 0.31 & 0.50 & 1.05 & 0.31 & 0.39 \\
\hline $\mathrm{Eu}$ & 0.02 & 0.06 & 0.06 & 0.11 & 0.16 & 0.03 & 0.05 & 0.20 & 0.09 & 0.03 & 0.21 & 0.28 & 0.07 & 0.10 \\
\hline $\mathrm{Gd}$ & 0.05 & 0.31 & 0.24 & 0.60 & 0.48 & 0.09 & 0.20 & 0.58 & 0.35 & 0.28 & 0.77 & 1.19 & 0.28 & 0.67 \\
\hline $\mathrm{Tb}$ & 0.01 & 0.05 & 0.04 & 0.08 & 0.07 & 0.02 & 0.03 & 0.10 & 0.06 & 0.04 & 0.13 & 0.19 & 0.05 & 0.14 \\
\hline Dy & 0.05 & 0.38 & 0.35 & 0.34 & 0.42 & 0.13 & 0.21 & 0.66 & 0.36 & 0.23 & 0.93 & 1.08 & 0.36 & 0.94 \\
\hline Ho & 0.02 & 0.09 & 0.10 & 0.07 & 0.10 & 0.03 & 0.06 & 0.18 & 0.09 & 0.05 & 0.22 & 0.27 & 0.08 & 0.24 \\
\hline $\mathrm{Er}$ & 0.03 & 0.32 & 0.27 & 0.18 & 0.32 & 0.11 & 0.17 & 0.50 & 0.31 & 0.15 & 0.66 & 0.80 & 0.29 & 0.78 \\
\hline $\mathrm{Tm}$ & 0.01 & 0.05 & 0.05 & 0.03 & 0.06 & 0.02 & 0.03 & 0.08 & 0.05 & 0.03 & 0.11 & 0.12 & 0.05 & 0.11 \\
\hline $\mathrm{Yb}$ & 0.05 & 0.29 & 0.29 & 0.20 & 0.35 & 0.12 & 0.18 & 0.56 & 0.29 & 0.15 & 0.71 & 0.82 & 0.33 & 0.61 \\
\hline $\mathrm{Lu}$ & 0.01 & 0.05 & 0.05 & 0.03 & 0.07 & 0.03 & 0.03 & 0.10 & 0.06 & 0.02 & 0.13 & 0.13 & 0.06 & 0.10 \\
\hline$\sum$ ETR & & 5.30 & 4.45 & 10.00 & 15.81 & 4.02 & 2.44 & 7.98 & 13.71 & 11.88 & 15.15 & 22.98 & 14.11 & 10.21 \\
\hline${ }^{\mathrm{a}} \mathrm{Pr} / \mathrm{Yb} \mathrm{b}_{(\mathrm{SN})}$ & & 0.22 & 0.17 & 0.65 & 0.61 & 0.37 & 0.12 & 0.15 & 0.70 & 0.62 & 0.26 & 0.37 & 0.61 & 0.17 \\
\hline${ }^{\mathrm{b}} \mathrm{Eu} / \mathrm{Eu}^{*}{ }_{(\mathrm{SN})}$ & & 1.23 & 1.59 & 1.16 & 1.45 & 1.36 & 1.79 & 1.93 & 1.12 & 0.52 & 1.69 & 1.26 & 1.11 & 0.87 \\
\hline${ }^{\mathrm{c}} \mathrm{Ce} / \mathrm{Ce}^{*}{ }_{(\mathrm{SN})}$ & & 0.77 & 0.79 & 0.87 & 0.83 & 0.90 & 0.68 & 0.76 & 1.02 & 2.44 & 0.96 & 1.02 & 0.99 & 0.80 \\
\hline${ }^{\mathrm{d}} \mathrm{Y} / \mathrm{Y}^{*}{ }_{(\mathrm{SN})}$ & & 1.89 & 1.60 & 1.29 & 1.79 & 1.66 & 1.97 & 1.68 & 1.72 & 1.56 & 1.27 & 1.56 & 1.60 & 1.59 \\
\hline $\mathrm{Y} / \mathrm{Ho}$ & & 48.89 & 38.00 & 35.71 & 46.00 & 43.33 & 46.67 & 40.56 & 43.33 & 42.00 & 32.73 & 39.26 & 42.50 & 39.58 \\
\hline${ }^{\mathrm{e}} \mathrm{Pr} / \mathrm{Yb}_{(\mathrm{CN})}$ & & 1.25 & 0.94 & 3.71 & 3.47 & 2.11 & 0.70 & 0.87 & 3.99 & 3.50 & 1.48 & 2.10 & 3.46 & 0.98 \\
\hline${ }^{\mathrm{f}} \mathrm{Eu} / \mathrm{Eu}^{*}{ }_{(\mathrm{CN})}$ & & 0.37 & 0.48 & 0.32 & 0.44 & 0.47 & 0.51 & 0.60 & 0.35 & 0.15 & 0.52 & 0.38 & 0.36 & 0.30 \\
\hline${ }^{\mathrm{g}} \mathrm{Ce} / \mathrm{Ce}^{*}{ }_{(\mathrm{CN})}$ & & 0.37 & 0.38 & 0.42 & 0.40 & 0.42 & 0.33 & 0.38 & 0.50 & 1.16 & 0.47 & 0.51 & 0.47 & 0.39 \\
\hline
\end{tabular}

Notes.

a b c dPAAS normalization values based on McLennan (1989).

e ${ }^{g}{ }$ Chondrite normalization based on Taylor and McLennan (1985).

${ }^{\mathrm{b}} \mathrm{Eu} / \mathrm{Eu}^{*}{ }_{(\mathrm{SN})}=\mathrm{Eu}_{(\mathrm{SN})} / 0.66 \mathrm{Sm}_{(\mathrm{SN})}+0.33 \mathrm{~Tb}_{(\mathrm{SN})}$

${ }^{\mathrm{c}} \mathrm{Ce} / \mathrm{Ce}^{*}{ }_{(\mathrm{SN})}=\mathrm{Ce}_{(\mathrm{SN})} / 0.5 \mathrm{La}_{(\mathrm{SN})}+0.5 \mathrm{Pr}_{(\mathrm{SN})}$.

${ }^{\mathrm{d}} \mathrm{Y} / \mathrm{Y}^{*}(\mathrm{SN})=\mathrm{Y}_{(\mathrm{SN})} / 0.5 \mathrm{Dy} \mathrm{(SN}_{(\mathrm{SN})}+0.5 \mathrm{Ho}_{(\mathrm{SN})}$.

${ }^{\mathrm{f}} \mathrm{Eu} / \mathrm{Eu}^{*}{ }_{(\mathrm{CN})}=\mathrm{Eu}_{(\mathrm{CN})} / \mathrm{Sm}_{(\mathrm{CN})}+\mathrm{Gd}_{(\mathrm{CN})}$.

${ }^{g} \mathrm{Ce} / \mathrm{Ce}^{*}{ }_{(\mathrm{CN})}=\mathrm{Ce}_{(\mathrm{CN})} / \mathrm{La}_{(\mathrm{CN})}+\operatorname{Pr}_{(\mathrm{CN})}$.

bdl - below detection limit. 


\section{Appendix E. U-Pb-Th SHRIMP data}

U-Pb-Th SHRIMP data of detrital zircon grains from sample PTG106.

\begin{tabular}{|c|c|c|c|c|c|c|c|c|c|c|c|c|c|c|c|c|c|c|c|}
\hline Spot & $\mathrm{U} \mathrm{ppm}$ & Th ppm & ${ }^{232} \mathrm{Th} /{ }^{238} \mathrm{U}$ & ${ }^{206} \mathrm{~Pb} \mathrm{ppm}$ & $4 \mathrm{f}^{206} \%$ & ${ }^{207} \mathrm{~Pb} /{ }^{206} \mathrm{~Pb}$ & \pm & ${ }^{207} \mathrm{~Pb} /{ }^{235} \mathrm{U}$ & \pm & ${ }^{206} \mathrm{~Pb} /{ }^{238} \mathrm{U}$ & \pm & $\begin{array}{l}\text { Error } \\
\text { correlation }\end{array}$ & ${ }^{208} \mathrm{~Pb} /{ }^{232} \mathrm{Th}$ & \pm & Age ${ }^{206} \mathrm{~Pb} /{ }^{238} \mathrm{U}$ & \pm & Age ${ }^{206} \mathrm{~Pb} / 207 \mathrm{~Pb}$ & \pm & Disc. \% \\
\hline D.1-1 & 262 & 214 & 0.84 & 71.1 & 0.00 & 0.10667 & 0.65 & 4.6463 & 1.53 & 0.3159 & 1.39 & 0.907 & 0.0913 & 1.57 & 1770 & 22 & 1743 & 12 & -2 \\
\hline D.1-2 & 294 & 154 & 0.54 & 102.8 & 0.22 & 0.17350 & 0.53 & 9.7109 & 1.38 & 0.4059 & 1.28 & 0.925 & 0.1036 & 1.77 & 2196 & 24 & 2592 & 9 & 15 \\
\hline D.1-3 & 194 & 135 & 0.72 & 65.4 & 0.00 & 0.13824 & 0.81 & 7.4771 & 1.58 & 0.3923 & 1.36 & 0.860 & 0.1075 & 1.72 & 2133 & 25 & 2205 & 14 & 3 \\
\hline D.1-4 & 109 & 65 & 0.62 & 29.9 & 0.00 & 0.10692 & 0.97 & 4.7228 & 1.79 & 0.3204 & 1.50 & 0.839 & 0.0895 & 1.95 & 1791 & 24 & 1748 & 18 & -3 \\
\hline D.2-1 & 101 & 42 & 0.44 & 30.5 & 0.50 & 0.13282 & 1.55 & 6.4144 & 2.18 & 0.3503 & 1.53 & 0.702 & 0.1084 & 3.87 & 1936 & 26 & 2136 & 27 & 9 \\
\hline D.2-4 & 400 & 50 & 0.13 & 165.9 & 0.03 & 0.19986 & 0.35 & 13.3016 & 1.29 & 0.4827 & 1.24 & 0.962 & 0.1289 & 2.46 & 2539 & 26 & 2825 & 6 & 10 \\
\hline D.3-1 & 208 & 84 & 0.42 & 90.0 & 0.12 & 0.19636 & 0.66 & 13.6141 & 1.49 & 0.5029 & 1.33 & 0.895 & 0.1285 & 1.92 & 2626 & 29 & 2796 & 11 & 6 \\
\hline D.3-2 & 301 & 228 & 0.78 & 155.4 & 0.03 & 0.26162 & 0.32 & 21.6967 & 1.32 & 0.6015 & 1.28 & 0.971 & 0.1522 & 1.40 & 3036 & 31 & 3257 & 5 & 7 \\
\hline D.3-3 & 122 & 62 & 0.52 & 58.5 & 0.20 & 0.22055 & 0.64 & 17.0043 & 1.60 & 0.5592 & 1.47 & 0.916 & 0.1408 & 2.43 & 2863 & 34 & 2985 & 10 & 4 \\
\hline D.5-1 & 119 & 60 & 0.52 & 54.1 & 0.06 & 0.19991 & 0.60 & 14.6355 & 1.59 & 0.5310 & 1.48 & 0.927 & 0.1420 & 1.86 & 2746 & 33 & 2825 & 10 & 3 \\
\hline D.5-2 & 111 & 118 & 1.10 & 34.2 & 0.00 & 0.12553 & 0.85 & 6.2057 & 1.74 & 0.3586 & 1.51 & 0.872 & 0.0974 & 1.78 & 1975 & 26 & 2036 & 15 & 3 \\
\hline D.5-3 & 224 & 118 & 0.54 & 97.5 & 0.02 & 0.18515 & 0.45 & 12.9330 & 1.40 & 0.5066 & 1.32 & 0.946 & 0.1346 & 2.27 & 2642 & 29 & 2700 & 7 & 2 \\
\hline D.5-5 & 74 & 34 & 0.47 & 35.8 & -0.14 & 0.20712 & 0.90 & 16.1018 & 1.92 & 0.5638 & 1.70 & 0.883 & 0.1505 & 2.93 & 2882 & 39 & 2883 & 15 & 0 \\
\hline D.6-1 & 134 & 95 & 0.73 & 34.4 & 0.12 & 0.10657 & 0.95 & 4.3834 & 1.75 & 0.2983 & 1.47 & 0.842 & 0.0842 & 1.86 & 1683 & 22 & 1742 & 17 & 3 \\
\hline D.6-4 & 121 & 110 & 0.93 & 55.0 & 0.08 & 0.19941 & 0.62 & 14.5081 & 1.59 & 0.5277 & 1.47 & 0.922 & 0.1405 & 1.73 & 2732 & 33 & 2821 & 10 & 3 \\
\hline D.6-3 & 159 & 153 & 0.99 & 38.1 & 0.27 & 0.10239 & 1.26 & 3.9253 & 1.91 & 0.2781 & 1.44 & 0.751 & 0.0786 & 1.90 & 1582 & 20 & 1668 & 23 & 5 \\
\hline D.6-2 & 40 & 33 & 0.85 & 10.4 & 0.06 & 0.10690 & 2.33 & 4.4365 & 3.11 & 0.3010 & 2.05 & 0.660 & 0.0824 & 3.55 & 1696 & 31 & 1747 & 43 & 3 \\
\hline D.7-1 & 255 & 77 & 0.31 & 109.9 & 0.06 & 0.19860 & 0.40 & 13.7201 & 1.54 & 0.5010 & 1.48 & 0.965 & 0.1264 & 2.12 & 2618 & 32 & 2815 & 7 & 7 \\
\hline D.7-2 & 108 & 59 & 0.57 & 39.5 & 0.02 & 0.14303 & 0.73 & 8.4108 & 1.82 & 0.4265 & 1.66 & 0.916 & 0.1177 & 2.01 & 2290 & 32 & 2264 & 13 & -1 \\
\hline D.7-3 & 270 & 26 & 0.10 & 76.0 & 0.02 & 0.12781 & 0.56 & 5.7634 & 1.65 & 0.3271 & 1.55 & 0.941 & 0.1014 & 3.19 & 1824 & 25 & 2068 & 10 & 12 \\
\hline D.8-1 & 275 & 229 & 0.86 & 114.6 & 0.13 & 0.18335 & 0.54 & 12.2479 & 2.59 & 0.4845 & 2.54 & 0.978 & 0.1214 & 2.67 & 2547 & 53 & 2683 & 9 & 5 \\
\hline D. $8-2$ & 202 & 258 & 1.32 & 106.7 & 0.02 & 0.26831 & 0.48 & 22.7538 & 1.52 & 0.6150 & 1.44 & 0.948 & 0.1570 & 1.58 & 3090 & 35 & 3296 & 8 & 6 \\
\hline D.8-3 & 315 & 287 & 0.94 & 79.4 & 0.14 & 0.12017 & 0.82 & 4.8525 & 1.52 & 0.2929 & 1.28 & 0.840 & 0.0834 & 1.58 & 1656 & 19 & 1959 & 15 & 15 \\
\hline D. $8-4$ & 264 & 242 & 0.95 & 79.0 & 0.06 & 0.12455 & 0.74 & 5.9707 & 1.57 & 0.3477 & 1.38 & 0.882 & 0.0934 & 1.63 & 1924 & 23 & 2022 & 13 & 5 \\
\hline D.9-1 & 656 & 126 & 0.20 & 105.4 & 0.36 & 0.09993 & 1.03 & 2.5690 & 1.59 & 0.1865 & 1.21 & 0.760 & 0.0533 & 4.06 & 1102 & 12 & 1741 & 19 & 32 \\
\hline D.9-2 & 236 & 141 & 0.62 & 60.9 & 0.04 & 0.10630 & 1.03 & 4.4089 & 1.69 & 0.3008 & 1.34 & 0.792 & 0.0830 & 1.96 & 1695 & 20 & 1737 & 19 & 2 \\
\hline D.9-3 & 89 & 75 & 0.88 & 24.2 & 0.45 & 0.10740 & 1.86 & 4.6584 & 2.54 & 0.3146 & 1.73 & 0.681 & 0.0842 & 2.73 & 1763 & 27 & 1756 & 34 & 0 \\
\hline D. $10-1$ & 152 & 164 & 1.12 & 39.7 & 0.14 & 0.10539 & 1.13 & 4.4228 & 1.86 & 0.3044 & 1.48 & 0.795 & 0.0841 & 1.85 & 1713 & 22 & 1721 & 21 & 0 \\
\hline D. $10-2$ & 65 & 26 & 0.41 & 32.8 & 0.12 & 0.22360 & 0.91 & 18.0096 & 2.03 & 0.5842 & 1.81 & 0.894 & 0.1492 & 2.74 & 2966 & 43 & 3007 & 15 & 1 \\
\hline D. $12-2$ & 73 & 43 & 0.61 & 20.2 & 0.15 & 0.10714 & 1.43 & 4.7641 & 2.23 & 0.3225 & 1.72 & 0.768 & 0.0894 & 2.55 & 1802 & 27 & 1751 & 26 & -3 \\
\hline
\end{tabular}

Notes: Isotopic ratios errors in \%

All $\mathrm{Pb}$ in ratios are radiogenic component. All corrected for ${ }^{204} \mathrm{~Pb}$

disc. $=$ discordance. As $\left.100-100\left\{\left.\mathrm{t}\right|^{206} \mathrm{~Pb} /{ }^{203} \mathrm{U}\right] / \mathrm{t}^{207} \mathrm{~Pb} /{ }^{206} \mathrm{~Pb}\right]$.

$4 \mathrm{f}^{206}=\left(\right.$ common $\left.{ }^{206} \mathrm{~Pb}\right) /\left(\right.$ total measured $\left.{ }^{206} \mathrm{~Pb}\right)$ based on measured ${ }^{204} \mathrm{~Pb}$.

Uncertainties are $1 \sigma ;$ n.a. $=$ not available. 
$\mathrm{U}-\mathrm{Pb}-\mathrm{Th}$ SHRIMP data of detrital zircon grains from sample PTG93.

\begin{tabular}{|c|c|c|c|c|c|c|c|c|c|c|c|c|c|c|c|c|c|c|c|}
\hline Spot & $\mathrm{U}$ ppm & Th ppm & ${ }^{232} \mathrm{Th} /{ }^{238} \mathrm{U}$ & ${ }^{206} \mathrm{~Pb} \mathrm{ppm}$ & $4 \mathrm{f}^{206} \%$ & ${ }^{207} \mathrm{~Pb} /{ }^{206} \mathrm{~Pb}$ & \pm & ${ }^{207} \mathrm{~Pb} /{ }^{235} \mathrm{U}$ & \pm & ${ }^{206} \mathrm{~Pb} /{ }^{238} \mathrm{U}$ & \pm & Error correlation & ${ }^{208} \mathrm{~Pb} /{ }^{232} \mathrm{Th}$ & \pm & Age ${ }^{206} \mathrm{~Pb} /{ }^{238} \mathrm{U}$ & \pm & Age ${ }^{206} \mathrm{~Pb} /{ }^{207} \mathrm{~Pb}$ & \pm & Disc. \% \\
\hline E.1-1 & 311 & 98 & 0.33 & 92.6 & -0.01 & 0.12559 & 0.53 & 6.00 & 1.39 & 0.3466 & 1.28 & 0.924 & 0.0972 & 1.63 & 1918 & 21 & 2037 & 9 & 6 \\
\hline E.1-2 & 39 & 26 & 0.696 & 10.2 & 0.00 & 0.10721 & 1.73 & 4.5694 & 2.72 & 0.3091 & 2.10 & 0.772 & 0.0889 & 2.97 & 1736 & 32 & 1753 & 32 & 1 \\
\hline E.1-3 & 117 & 37 & 0.323 & 31.9 & 0.91 & 0.18179 & 1.62 & 7.8879 & 2.24 & 0.3147 & 1.55 & 0.690 & 0.1216 & 5.91 & 1764 & 24 & 2669 & 27 & 34 \\
\hline E. $2-1$ & 362 & 158 & 0.452 & 131.5 & 0.04 & 0.16960 & 0.51 & 9.8920 & 1.37 & 0.4230 & 1.27 & 0.928 & 0.1102 & 1.59 & 2274 & 24 & 2554 & 9 & 11 \\
\hline E. $2-2$ & 194 & 145 & 0.772 & 83.8 & 0.09 & 0.21483 & 0.49 & 14.8491 & 1.42 & 0.5013 & 1.34 & 0.939 & 0.1405 & 1.58 & 2619 & 29 & 2942 & 8 & 11 \\
\hline E. $2-4$ & 294 & 147 & 0.517 & 123.6 & 0.00 & 0.18287 & 0.45 & 12.3209 & 1.35 & 0.4887 & 1.28 & 0.942 & 0.1323 & 1.45 & 2565 & 27 & 2679 & 7 & 4 \\
\hline E.3-1 & 278 & 128 & 0.477 & 130.6 & 0.02 & 0.20086 & 0.38 & 15.1436 & 1.40 & 0.5468 & 1.35 & 0.962 & 0.1437 & 1.56 & 2812 & 31 & 2833 & 6 & 1 \\
\hline E.3-2 & 196 & 178 & 0.940 & 62.4 & 0.05 & 0.12918 & 0.90 & 6.6152 & 1.63 & 0.3714 & 1.35 & 0.832 & 0.1050 & 1.57 & 2036 & 24 & 2087 & 16 & 2 \\
\hline E.3-3 & 244 & 101 & 0.428 & 67.0 & 0.00 & 0.12344 & 0.61 & 5.4396 & 1.52 & 0.3196 & 1.39 & 0.915 & 0.1150 & 1.64 & 1788 & 22 & 2007 & 11 & 11 \\
\hline E.4-1 & 1208 & 6 & 0.005 & 84.6 & -0.04 & 0.05726 & 1.03 & 0.6440 & 1.58 & 0.0816 & 1.20 & 0.760 & 0.0422 & 42.32 & 506 & 6 & 502 & 23 & -1 \\
\hline E.4-2 & 114 & 95 & 0.864 & 40.2 & 0.15 & 0.13834 & 0.96 & 7.8163 & 1.76 & 0.4098 & 1.47 & 0.838 & 0.1140 & 1.95 & 2214 & 28 & 2207 & 17 & 0 \\
\hline E.4-3 & 101 & 83 & 0.842 & 43.9 & 0.08 & 0.19787 & 0.72 & 13.7271 & 1.65 & 0.5031 & 1.48 & 0.900 & 0.0848 & 8.40 & 2627 & 32 & 2809 & 12 & 6 \\
\hline E.5-1 & 144 & 124 & 0.885 & 44.6 & 0.00 & 0.12579 & 0.76 & 6.2288 & 1.62 & 0.3591 & 1.44 & 0.885 & 0.0990 & 1.69 & 1978 & 24 & 2040 & 13 & 3 \\
\hline E.5-2 & 49 & 40 & 0.856 & 16.5 & 0.30 & 0.13025 & 1.81 & 7.0573 & 2.60 & 0.3930 & 1.87 & 0.719 & 0.1112 & 3.00 & 2137 & 34 & 2101 & 32 & -2 \\
\hline E.5-3 & 77 & 52 & 0.705 & 27.4 & 0.29 & 0.13350 & 1.67 & 7.6021 & 2.33 & 0.4130 & 1.63 & 0.699 & 0.1134 & 3.20 & 2229 & 31 & 2144 & 29 & -4 \\
\hline E.6-1 & 127 & 103 & 0.839 & 34.2 & 0.08 & 0.10772 & 1.26 & 4.6621 & 1.94 & 0.3139 & 1.48 & 0.761 & 0.0890 & 2.06 & 1760 & 23 & 1761 & 23 & 0 \\
\hline E.6-2 & 143 & 61 & 0.440 & 61.7 & 0.04 & 0.18461 & 0.64 & 12.8018 & 1.56 & 0.5029 & 1.42 & 0.911 & 0.1352 & 3.25 & 2626 & 31 & 2695 & 11 & 3 \\
\hline E.6-3 & 157 & 126 & 0.832 & 40.0 & 0.10 & 0.10776 & 1.30 & 4.4101 & 1.94 & 0.2968 & 1.44 & 0.740 & 0.0881 & 2.47 & 1675 & 21 & 1762 & 24 & 5 \\
\hline E.6-4 & 102 & 70 & 0.708 & 28.2 & 0.11 & 0.10863 & 1.38 & 4.8156 & 2.07 & 0.3215 & 1.54 & 0.744 & 0.0908 & 2.37 & 1797 & 24 & 1777 & 25 & -1 \\
\hline E.7-1 & 125 & 195 & 1.61 & 39.6 & 0.77 & 0.12699 & 3.16 & 6.41 & 3.57 & .3661 & 1.67 & 0.468 & 0.1037 & 2.84 & 2011 & 29 & 2057 & 56 & 2 \\
\hline E.7-2 & 80 & 17 & 0.223 & 26.8 & 0.33 & 0.13328 & 1.30 & 7.1350 & 2.20 & 0.3883 & 1.78 & 0.807 & 0.1029 & 6.12 & 2115 & 32 & 2142 & 23 & 1 \\
\hline E.7-3 & 313 & 162 & 0.536 & 126.4 & 0.03 & 0.17640 & 0.40 & 11.4273 & 1.51 & 0.4698 & 1.46 & 0.965 & 0.1283 & 1.63 & 2483 & 30 & 2619 & 7 & 5 \\
\hline E.8-1 & 87 & 71 & 0.842 & 45.0 & 0.02 & 0.23919 & 0.60 & 19.7697 & 1.80 & 0.5995 & 1.70 & 0.942 & 0.1639 & 1.90 & 3028 & 41 & 3115 & 10 & 3 \\
\hline E. $8-2$ & 83 & 45 & 0.557 & 42.4 & 0.26 & 0.26882 & 0.66 & 22.0542 & 1.93 & 0.5950 & 1.82 & 0.940 & 0.1553 & 2.67 & 3010 & 44 & 3299 & 10 & 9 \\
\hline E.8-3 & 70 & 38 & 0.565 & 25.3 & 0.36 & 0.14654 & 1.36 & 8.4990 & 2.30 & 0.4206 & 1.85 & 0.805 & 0.1096 & 3.56 & 2263 & 35 & 2306 & 23 & 2 \\
\hline E. $8-4$ & 102 & 80 & 0.811 & 35.6 & 0.21 & 0.14232 & 0.92 & 7.9195 & 1.95 & 0.4036 & 1.71 & 0.880 & 0.1092 & 2.16 & 2185 & 32 & 2256 & 16 & 3 \\
\hline E.9-1 & 101 & 41 & 0.417 & 33.3 & 0.19 & 0.13135 & 1.15 & 6.9519 & 2.06 & 0.3838 & 1.70 & 0.828 & 0.1092 & 3.18 & 2094 & 30 & 2116 & 20 & 1 \\
\hline E.9-2 & 70 & 74 & 1.091 & 37.1 & 0.07 & 0.23736 & 0.68 & 20.1939 & 1.92 & 0.6170 & 1.79 & 0.934 & 0.1627 & 2.08 & 3098 & 44 & 3102 & 11 & 0 \\
\hline E.9-3 & 380 & 111 & 0.303 & 128.8 & 0.05 & 0.20350 & 0.36 & 11.0705 & 1.53 & 0.3945 & 1.48 & 0.972 & 0.1014 & 1.79 & 2144 & 27 & 2854 & 6 & 25 \\
\hline E.9-4 & 81 & 35 & 0.448 & 39.4 & 0.08 & 0.21746 & 0.69 & 16.9792 & 1.88 & 0.5663 & 1.75 & 0.931 & 0.1505 & 2.55 & 2893 & 41 & 2962 & 11 & 2 \\
\hline E.9-5 & 242 & 232 & 0.990 & 73.9 & 0.02 & 0.13348 & 0.56 & 6.5372 & 1.68 & 0.3552 & 1.58 & 0.943 & 0.0895 & 4.39 & 1959 & 27 & 2144 & 10 & 9 \\
\hline
\end{tabular}

Notes: Isotopic ratios errors in \%.

All $\mathrm{Pb}$ in ratios are radiogenic component. All corrected for ${ }^{204} \mathrm{~Pb}$.

disc. $=$ discordance. as $\left.100-100\left\{t\left[^{206} \mathrm{~Pb} /{ }^{238} \mathrm{U}\right] / \mathrm{t}^{207} \mathrm{~Pb} /{ }^{206} \mathrm{~Pb}\right]\right\}$

$4 \mathrm{f}^{206}=\left(\right.$ common $\left.{ }^{206} \mathrm{~Pb}\right) /\left(\right.$ total measured $\left.{ }^{206} \mathrm{~Pb}\right)$ based on measured ${ }^{204} \mathrm{~Pb}$.

Uncertainties are $1 \sigma ;$ n.a. $=$ not available. 
$\mathrm{U}-\mathrm{Pb}-\mathrm{Th}$ SHRIMP data of detrital zircon grains from sample PTG226.

\begin{tabular}{|c|c|c|c|c|c|c|c|c|c|c|c|c|c|c|c|c|c|c|c|}
\hline Spot & $\mathrm{U}$ ppm & Th ppm & ${ }^{232} \mathrm{Th} /{ }^{238} \mathrm{U}$ & ${ }^{206} \mathrm{~Pb} \mathrm{ppm}$ & $4 \mathrm{f}^{206} \%$ & ${ }^{207} \mathrm{~Pb} /{ }^{206} \mathrm{~Pb}$ & \pm & ${ }^{207} \mathrm{~Pb} /\left.\right|^{235} \mathrm{U}$ & \pm & ${ }^{206} \mathrm{~Pb} /{ }^{238} \mathrm{U}$ & \pm & Error correlation & ${ }^{208} \mathrm{~Pb} /{ }^{232} \mathrm{Th}$ & \pm & Age ${ }^{206} \mathrm{~Pb} /{ }^{238} \mathrm{U}$ & \pm & Age ${ }^{206} \mathrm{~Pb} /{ }^{207} \mathrm{~Pb}$ & \pm & Disc. \% \\
\hline C.1-1 & 169 & 77 & 0.47 & 81.7 & 0.11 & 0.20991 & 0.53 & 16.3015 & 1.52 & 0.5632 & 1.42 & 0.938 & 0.1383 & 2.01 & 2880 & 33 & 2905 & 9 & 1 \\
\hline C.1-2 & 220 & 227 & 1.07 & 101.0 & 0.06 & 0.20335 & 0.44 & 14.9962 & 1.44 & 0.5349 & 1.37 & 0.952 & 0.0739 & 1.63 & 2762 & 31 & 2853 & 7 & 3 \\
\hline C.1-3 & 226 & 15 & 0.07 & 105.5 & 0.08 & 0.19831 & 0.43 & 14.8660 & 1.43 & 0.5437 & 1.36 & 0.954 & 0.0907 & 5.46 & 2799 & 31 & 2812 & 7 & 0 \\
\hline C.1-4 & 44 & 18 & 0.42 & 15.0 & 0.14 & 0.13289 & 1.58 & 7.2243 & 2.53 & 0.3943 & 1.98 & 0.782 & 0.1087 & 3.99 & 2143 & 36 & 2136 & 28 & 0 \\
\hline C.1-5 & 269 & 104 & 0.40 & 120.4 & 0.04 & 0.20349 & 0.42 & 14.6081 & 1.41 & 0.5206 & 1.34 & 0.955 & 0.1092 & 1.89 & 2702 & 30 & 2854 & 7 & 5 \\
\hline C.2-1 & 152 & 53 & 0.36 & 71.9 & -0.04 & 0.21055 & 0.56 & 16.0259 & 1.66 & 0.5520 & 1.57 & 0.942 & 0.1438 & 2.09 & 2834 & 36 & 2910 & 9 & 3 \\
\hline C.2-2 & 172 & 86 & 0.52 & 80.9 & 0.08 & 0.20849 & 0.55 & 15.7529 & 1.64 & 0.5480 & 1.54 & 0.941 & 0.1418 & 1.99 & 2817 & 35 & 2894 & 9 & 3 \\
\hline C.2-3 & 212 & 141 & 0.69 & 94.6 & -0.01 & 0.18558 & 0.50 & 13.3223 & 1.63 & 0.5206 & 1.55 & 0.952 & 0.1382 & 1.73 & 2702 & 34 & 2703 & 8 & 0 \\
\hline C. $2-4$ & 253 & 224 & 0.92 & 85.0 & 0.00 & 0.13344 & 0.59 & 7.1984 & 1.60 & 0.3912 & 1.48 & 0.929 & 0.1067 & 1.65 & 2129 & 27 & 2144 & 10 & 1 \\
\hline C. $2-5$ & 85 & 58 & 0.71 & 48.5 & -0.02 & 0.26320 & 0.66 & 24.1981 & 1.83 & 0.6668 & 1.71 & 0.933 & 0.1751 & 2.04 & 3293 & 44 & 3266 & 10 & -1 \\
\hline C.2-6 & 188 & 87 & 0.48 & 52.7 & 0.11 & 0.11039 & 0.89 & 4.9742 & 1.76 & 0.3268 & 1.52 & 0.863 & 0.0905 & 2.11 & 1823 & 24 & 1806 & 16 & -1 \\
\hline C.2-7 & 154 & 60 & 0.40 & 69.8 & 0.05 & 0.20291 & 0.78 & 14.7563 & 1.73 & 0.5274 & 1.54 & 0.892 & 0.1351 & 2.09 & 2731 & 34 & 2850 & 13 & 4 \\
\hline C.2-8 & 192 & 89 & 0.48 & 89.7 & 0.06 & 0.21145 & 0.49 & 15.8564 & 1.66 & 0.5439 & 1.58 & 0.956 & 0.1363 & 1.90 & 2800 & 36 & 2917 & 8 & 4 \\
\hline C.2-9 & 165 & 284 & 1.78 & 50.5 & 0.18 & 0.17468 & 0.76 & 8.5627 & 1.75 & 0.3555 & 1.57 & 0.900 & 0.0825 & 1.80 & 1961 & 27 & 2603 & 13 & 25 \\
\hline C. $2-10$ & 178 & 223 & 1.29 & 56.8 & 0.09 & 0.19055 & 0.63 & 9.7244 & 2.05 & 0.3701 & 1.95 & 0.952 & 0.0448 & 2.91 & 2030 & 34 & 2747 & 10 & 26 \\
\hline C.2-11 & 136 & 84 & 0.64 & 69.6 & 0.22 & 0.21472 & 0.60 & 17.5761 & 1.74 & 0.5937 & 1.63 & 0.939 & 0.1526 & 2.09 & 3004 & 39 & 2942 & 10 & -2 \\
\hline C.3-1 & 267 & 188 & 0.73 & 65.4 & -0.06 & 0.10579 & 0.89 & 4.1626 & 1.63 & 0.2854 & 1.37 & 0.840 & 0.0798 & 1.77 & 1618 & 20 & 1728 & 16 & 6 \\
\hline C.3-2 & 237 & 64 & 0.28 & 79.7 & 0.03 & 0.13292 & 0.64 & 7.1552 & 1.51 & 0.3904 & 1.37 & 0.906 & 0.1062 & 2.15 & 2125 & 25 & 2137 & 11 & 1 \\
\hline C.3-3 & 135 & 82 & 0.63 & 62.4 & 0.03 & 0.19610 & 0.65 & 14.5802 & 1.68 & 0.5392 & 1.54 & 0.922 & 0.1419 & 2.02 & 2780 & 35 & 2794 & 11 & 0 \\
\hline C.3-4 & 185 & 55 & 0.31 & 61.5 & 0.05 & 0.13241 & 0.76 & 7.0793 & 1.59 & 0.3878 & 1.40 & 0.879 & 0.1091 & 2.32 & 2112 & 25 & 2130 & 13 & 1 \\
\hline C.3-5 & 90 & 44 & 0.50 & 39.5 & 0.04 & 0.17887 & 0.82 & 12.5456 & 1.77 & 0.5087 & 1.57 & 0.886 & 0.1357 & 2.22 & 2651 & 34 & 2642 & 14 & 0 \\
\hline C. $4-1$ & 87 & 50 & 0.59 & 39.5 & -0.05 & 0.20573 & 0.78 & 14.9321 & 1.79 & 0.5264 & 1.61 & 0.901 & 0.1372 & 2.18 & 2726 & 36 & 2872 & 13 & 5 \\
\hline C.4-2 & 404 & 71 & 0.18 & 104.1 & 0.08 & 0.12076 & 0.80 & 4.9966 & 1.54 & 0.3001 & 1.32 & 0.856 & 0.0552 & 5.75 & 1692 & 20 & 1967 & 14 & 14 \\
\hline C. $4-3$ & 254 & 125 & 0.51 & 117.2 & 0.08 & 0.20033 & 0.57 & 14.8316 & 1.52 & 0.5370 & 1.41 & 0.928 & 0.1299 & 1.89 & 2771 & 32 & 2829 & 9 & 2 \\
\hline C.4-4 & 289 & 199 & 0.71 & 88.7 & 0.29 & 0.13311 & 0.91 & 6.5390 & 1.59 & 0.3563 & 1.31 & 0.821 & 0.1017 & 2.13 & 1965 & 22 & 2139 & 16 & 8 \\
\hline C.4-5 & 119 & 57 & 0.49 & 55.7 & -0.05 & 0.20991 & 1.58 & 15.7216 & 2.23 & 0.5432 & 1.58 & 0.707 & 0.1434 & 2.68 & 2797 & 36 & 2905 & 26 & 4 \\
\hline C.4-6 & 258 & 84 & 0.34 & 115.0 & 0.01 & 0.19598 & 0.58 & 14.0441 & 1.50 & 0.5197 & 1.39 & 0.924 & 0.1362 & 2.06 & 2698 & 31 & 2793 & 9 & 3 \\
\hline C.4-7 & 192 & 124 & 0.67 & 87.0 & 0.11 & 0.20324 & 0.52 & 14.7589 & 1.50 & 0.5267 & 1.40 & 0.937 & 0.1329 & 1.71 & 2727 & 31 & 2852 & 9 & 4 \\
\hline C.4-8 & 193 & 226 & 1.21 & 81.0 & 0.16 & 0.19640 & 0.60 & 13.2197 & 1.58 & 0.4882 & 1.47 & 0.926 & 0.1170 & 1.69 & 2563 & 31 & 2797 & 10 & 8 \\
\hline C.5-1 & 77 & 47 & 0.64 & 35.3 & 0.12 & 0.22630 & 0.72 & 16.7187 & 1.94 & 0.5358 & 1.81 & 0.928 & 0.1463 & 2.38 & 2766 & 41 & 3026 & 12 & 9 \\
\hline C.5-2 & 186 & 66 & 0.37 & 56.5 & 0.20 & 0.12896 & 0.92 & 6.2799 & 1.81 & 0.3532 & 1.56 & 0.861 & 0.0724 & 3.58 & 1950 & 26 & 2084 & 16 & 6 \\
\hline C.5-3 & 379 & 94 & 0.26 & 123.1 & 0.16 & 0.17144 & 0.45 & 8.9267 & 1.57 & 0.3776 & 1.50 & 0.957 & 0.0355 & 7.27 & 2065 & 27 & 2572 & 8 & 20 \\
\hline C.5-4 & 196 & 35 & 0.18 & 81.1 & 0.08 & 0.17064 & 0.55 & 11.3460 & 1.62 & 0.4822 & 1.53 & 0.942 & 0.1213 & 3.30 & 2537 & 32 & 2564 & 9 & 1 \\
\hline
\end{tabular}

Notes: Isotopic ratios errors in \%

$\mathrm{All} \mathrm{Pb}$ in ratios are radiogenic component. All corrected for ${ }^{204} \mathrm{~Pb}$

disc. $=$ discordance. as $\left.\left.100-100\left\{\left.\mathrm{t}\right|^{206} \mathrm{~Pb} / /^{238} \mathrm{U}\right] / \mathrm{t}^{207} \mathrm{~Pb} /{ }^{206} \mathrm{~Pb}\right]\right\}$.

$4 \mathrm{f}^{206}=\left(\right.$ common $\left.{ }^{206} \mathrm{~Pb}\right) /\left(\right.$ total measured $\left.{ }^{206} \mathrm{~Pb}\right)$ based on measured ${ }^{204} \mathrm{~Pb}$

Uncertainties are $1 \sigma ;$ n.a. $=$ not available. 


\section{References}

Alexander, B.W., Bau, M., Anderson, P., Dulski, P., 2008. Continentally-derived solutes in shallow Archean seawater: rare earth element and Nd isotope evidence in iron formation from the 2.9 Ga Pongola Supergroup, South Africa. Geochim. Cosmochim. Acta 72, 378-394.

Alibo, D.S., Nozaki, Y., 1999. Rare earth elements in seawater: particle association, shale normalization, and Ce oxidation. Geochim. Cosmochim. Acta 63, 363-372.

Alkmim, F.F., Marshak, S., 1998. Transamazonian Orogeny in the Southern São Francisco Craton Region, Minas Gerais, Brazil: evidence for Paleoproterozoic collision and collapse in the Quadrilátero Ferrufero. Precambrian Res. 90, 29-58.

Alkmim, F.F., Pedrosa-Soares, A.C., Noce, C.M., Cruz, S.C.P., 2007. Sobre a Evolução Tectônica do Orógeno Araçuaí-Congo Ocidental. Geonomos 15 (1), 25-43.

Almeida-Abreu, P.A., Knauer, L.G., Hartmann, M.B., Vieira dos Santos, G.G., Guimarães, M.L.V., de Abreu, F.R., Schrank, A., Pflug, R., 1989. Estratigrafia, faciologia e tectônica do Supergrupo Espinhaço na região de Serro - Conceição do Mato Dentro, Minas Gerais, Brasil. Zentralblatt für Geol. Palaöntol. (Teil I), 857-873.

Almeida-Abreu, P.A., Renger, F.E., 2002. Serra do Espinhaço Meridional: um orógeno de colisão do Mesoproterozóico. Rev. Bras. Geociênc. 32 (1), 1-14.

Almeida-Abreu, P.A., Renger, F.E., 2007. Stratigraphy and facies of the southern Serra do Espinhaço, Minas Gerais, Brazil. Z. dtsch. Ges. für Geowiss. 158, 9-29.

Babinski, M., Gradim, R.J., Pedrosa-Soares, A.C., Alkmim, F.F., Noce, C.M., Liu, D., 2005. Geocronologia U-Pb (SHRIMP) e Sm-Nd de xistos verdes basálticos do orógeno Araçuaí: Implicações para a idade do Grupo Macaúbas. Rev. Bras. Geociênc. 34 (4-supplemento), 77-81.

Bacon, C.R., Gunn, S.H., Lanphere, M.A., Wooden, J.L., 1994. Varied mantle sources and multi-level crustal contamination of magmas at Crater Lake, Oregon. In: Lanphere, M.A., Dalrymple, G.B., Turrin, B.D. (Eds.), Abstracts of the Eight International Conference on Geochronology, Cosmochronology and Isotope Geology. Berkeley, California, June 1994, U.S. Geological Survey Circular, vol. 1107, p. 17.

Baker, J.A., MacPherson, C.G., Menzies, M.A., Thirlwall, M.F., Al-Kadasi, M., Mattey, D.P., 2000. Resolving crustal and mantle contributions to continental flood volcanism, yemen; constraints from mineral oxygen isotope data. J. Petrol. 41 (12), 1805-1820.

Bau, M., Dulski, P., 1996. Distribution of yttrium and rare-earth elements in the Penge and Kuruman Iron-Formations, Transvaal Supergroup, South Africa. Precambrian Res. 79, 37-55.

Bau, M., Koschinsky, A., Dulski, P., Hein, J.R., 1996. Comparison of the partitioning behaviours of yttrium, rare earth elements and titanium between hydrogenetic marine ferromanganese crusts and seawater. Geochim. Cosmochim. Acta 60, 1709-1725.

Berman, R.G., 1991. Thermobarometry using multi-equilibrium calculations: a new technique, with petrological applications. In: Gordon, T.M., Martin, R.F. (Eds.), Quantitative Methods in Petrology: an Issue in Honor of Hugh J. Greenwood, Canadian Mineralogist, vol. 29, pp. 833-855.

Brito Neves, B.B., Fuck, R.A., Pimentel, M.M., 2014. The Brasiliano collage in South America: a review. Braz. J. Geol. 44 (3), 493-518.

Chemale Jr., F., Dussin, I.A., Alkmim, F.F., Martins, M.S., Queiroga, G., Armstrong, R., Santos, M.N., 2012. Unravelling a Proterozoic basin history through detrital zircon geochronology: the case of the Espinhaço Supergroup, Minas Gerais. Gondwana Res. 22, 200-206.

Danielson, A., Möller, P., Dulski, P., 1992. The europium anomalies in banded iron formation and the thermal history of the oceanic crust. Chem. Geol. 97, 89-100.

Dossin, I.A., Dossin, T.M., Charvet, J., Cocherie, A., Rossi, P., 1993. Single-zircon dating by step-wise Pb-evaporation of Middle Proterozoic Magmatismo in the Espinhaço Range, Southeastern São Francisco Craton (Minas Gerais, Brazil). In: Simpósiodo Cráton do São Francisco, 2, Salvador, Anais, pp. 39-42.

Dossin, T.M., Dossin, I.A., Dardenne, M.A., 1987. Geoquímica dos elementos terras raras das formações ferríferas da Serra da Serpentina, Conceição do Mato Dentro, Minas Gerais. Geochim. Bras. 1 (2), 151-160.

Dossin, T.M., 1985. Geologia e Geoquímica das formações ferríferas da Serra da Serpentina, Conceição do Mato Dentro - MG. Masters dissertation. Universidade de Brasília, p. 140.

Dussin, T.M., 1994. Late Proterozoic dyke swarm from the southeastern edge of the São Francisco Craton (SE Brazil): geochemistry and petrology. In: Dussin, T.M. (Ed.), Associations volcano-plutoniques de l'Espinhaço Meridional (SE-Brésil), Un exemple d'évolution de la croûte protérozoïque. Universidade de Orléans, p. 177. PhD thesis.

Dussin, T.M., Duarte, P., Dussin, I.A., 2000. Registro da tectônica Brasiliana na região de Guanhães (SE, Brasil): deformação e metamorfismo das rochas de idade pósTransamazônicas. Geonomos 8 (2), 55-59.

Dymek, R.F., Klein, C., 1988. Chemistry, petrology, and origin of banded iron formation lithologies from the 3800 Ma Isua supracrustal belt, West Greenland. Precambrien Res. 39, 247-302.

Elderfield, H., Sholkovitz, E.R., 1987. Rare earth elements in the pore waters of reducing nearshore sediments. Earth Planet. Sci. Lett. 82, 280-288.

Evensen, N.M., Hamilton, P.J., O'nions, R.K., 1978. Rare earth abundances in chondritic meteorites. Geochim. Cosmochim. Acta 42, 1199-1212.

Fernandes, M.L.S., 2001. O Granito Borrachudos entre Guanhães e Dores de Guanhães (Plutonito Morro do Urubu): Gênese e Evolução. PhD thesis. Departamento de Geologia, Universidade Federal do Rio do Janeiro, p. 187.

Fernandes, M.L.S., Fuzikawa, K., Correia Neves, J.M., Bilal, E., Leonardos, C.M.W., 2000. Fluids related to endoskarn formation process in the Guanhães área, Minas Gerais State, Brazil. Rev. Bras. Geociênc. 30 (2), 327-330.
Figueiredo e Silva, R.C., Lobato, L.M., Rosière, C.A., Hagemann, S., Zucchetti, M. Baars, F.J., Morais, R., Andrade, I., 2008. A hydrothermal origin for the jaspilitehosted, giant Serra Norte iron ore deposits in the Carajás Mineral Province, Pará state, Brazil. Soc. Econ. Geol. SEG Rev. 15, 255-290.

Gioia, S.M.C.L., Pimentel, M.M., 2000. The Sm-Nd isotopic method in the Geochrology Laboratory of the University of Brasília. An. Acad. Bras. Ciênc. 72 (2), 219-245.

Gradim, R.J., Alkmim, F.F., Pedrosa-Soares, A.C., Babinski, M., Noce, C.M., 2005. Xistos verdes do Alto Araçuaí, Minas Gerais; Vulcanismo básico do rifte neoproterozóico Macaúbas. Rev. Bras. Geociênc. 35 (4-supplemento), 59-69.

Grossi-Sad, J.H., Mourão, M.A.A., Guimarães, M.L.V., Knauer, L.G., 1997. Geologia da Folha Conceição do Mato Dentro. In: Grossi-Sad, J.H., Lobato, L.M., PedrosaSoares, A.C., Soares-Filho, B.S. (Eds.), Projeto Espinhaço em CD-Rom (textos, mapas e anexos). COMIG, pp. 2533-2693.

Guimarães, M.L.V., 1992. Petrogênese das rochas Pré-Cambrianas da região Itabira/ Morro do Pilar, borda sudeste da Serra do Espinhaço Meridional - MG. Masters dissertation. Universidade de São Paulo, p. 139.

Gutzmer, J., Chisonga, B.C., Beukes, N.J., Mukhopadhyay, J., 2008. The geochemistry of banded iron formation-hosted high-grade hematite-martite iron ores. In: Hagemann, S., Rosiere, C., Gutzmer, J., Beukes, N.J. (Eds.), Banded Iron Formation-related High-grade Iron Ore, Reviews in Economic Geology, Society of Economic Geologists, Denver, vol. 15, pp. 157-183.

Hagemann, S.G., Rosière, C.A., Gutzmer, J., Beukes, N.J., 2008. Glossary of terms banded iron-formation-related high-grade iron ore. Rev. Econ. Geol. 15, $411-414$.

Hartmann, L.A., Endo, I., Suita, M.T.F., Santos, J.O.S., Frantz, J.C., Carneiro, M.A., McNaughton, N.J., Barley, M.E., 2006. Provenance and age delimitation of Quadrilátero Ferrídero sandstones based on zircon U-Pb isotopes. J. S. Am. Earth Sci. 20, 273-285.

Holland, T.J.B., Powell, R., 1990. An internally-consistent thermodynamic dataset with uncertainties and correlations: the system $\mathrm{Na}_{2} \mathrm{O}-\mathrm{CaO}-\mathrm{MgO}-\mathrm{MnO}-\mathrm{FeO}-$ $\mathrm{Al}_{2} \mathrm{O}_{3}-\mathrm{SiO}_{2}-\mathrm{TiO}_{2}-\mathrm{C}-\mathrm{H}_{2}-\mathrm{O}_{2}$. J. Metamorph. Geol. 8, 89-124.

Klein, C., Ladeira, E.A., 2004. Geochemistry and mineralogy of the Neoproterozoic banded iron-formations and some selected, siliceous manganese formations from the Urucum district, Mato Grosso do Sul, Brazil. Econ. Geol. 99, 1233-1244.

Klein, C., 2005. Some Precambrian banded iron-formations (BIFs) from around the world: their age, geologic setting, mineralogy, metamorphism, geochemistry, and origin. Am. Mineral. 90, 1473-1499.

Leake, B.E., Woolley, A.R., Arps, C.E.S., Birch, W.D., Gilbert, M.C., Grice, J.D., Hawthorne, F.C., Kato, A., Kisch, H.J., Krivovichev, V.G., Linthout, K., Laird, J., Mandarino, J.A., Maresch, W.V., Nickel, E.H., Rock, N.M.S., Schumacher, J.C. Smith, D.C., Stephenson, N.C.N., Ungaretti, L., Whittaker, E.J.W., Youzhi, G., 1997 Nomenclature of amphiboles: report of the subcommittee on amphiboles of the International Mineralogical Association, commission on new minerals and mineral names. Can. Mineral. 82, 219-246.

Ludwig, K.R., 2001. SQUID 1.02: a Users Manual. Berkeley Geochronology Centre, p. 19. Special Publication No. 2.

Ludwig, K.R., 2003. ISOPLOT 3.00 - a Geochronological Toolkit for Excel. Berkely Geochronology Center, p. 67. Special Publication 4.

Machado, N., Schrank, A., de Abreu, F.R., Knauer, L.G., Almeida-Abreu, P.A., 1989. Resultados preliminares da geocronologia U/Pb na Serra do Espinhaço Meridional. Simpósio Geol. Minas Gerais 5, 171-174.

Martins, M.S., 2006. Geologia dos diamantes e carbonados aluvionares da bacia do Rio Macaúbas, MG. PhD thesis. Instituto de Geociências, Universidade Federal de Minas Gerais, p. 231.

McLennan, S.M., 1989. Rare earth elements in sedimentary rocks: influence of provenance and sedimentary processes. In: Lipin, B.R., McKay, G.A. (Eds.), Geochemistry and Mineralogy of Rare Earth Elements, Reviews in Mineralogy, vol. 21, pp. 169-200.

McLennan, S.M., Taylor, S.R., 1991. Sedimentary rocks and crustal evolution: tectonic setting and secular trends. J. Geol. 99, 1-21.

Michard, A., 1989. Rare earth element systematics in hydrothermal fluids. Geochim. Cosmochim. Acta 53, 745-750.

Michard, A., Albarède, F., Michard, G., Minster, J.F., Charlou, J.L., 1983. Rare-earth elements and uranium in high-temperature solutions from East Pacific Rise hydrothermal vent field $\left(13^{\circ} \mathrm{N}\right)$. Nature 303, 795-797.

Moorbath, S., O'Nions, R.K., Pankhurst, R.J., 1973. Early archaean age for the Isua iron-formation, West Greenland. Nature 245, 138.

Noce, C.M., Pedrosa-Soares, A.C., Grossi-Sad, J.H., Baars, F.J., Guimarães, M.L.V Mourão, M.A.A., Oliveira, M.J.R., Roque, N.C., 1997. Nova divisão estratigráfica regional do Grupo Macaúbas na Faixa Araçuaí: o registro de uma bacia neoproterozóica. In: SBG, Simp. Geol. MG, 9, Anais, vol. 14, pp. 29-31.

Noce, C.M., Pedrosa-Soares, A.C., Silva, L.C., Alkmim, F.F., 2007. O Embasamento Arqueano e Paleoproterozóico do Orógeno Araçuaí. Geonomos 15 (1), 17-23.

Oliveira, A.Z.K., 2002. Estruturação e alteração metassomática do ortognaisse Açucena (Suíte Borrachudos) na região de Ipatinga, Minas Gerais. Masters dissertation. Departamento de Geologia, Universidade Federal de Minas Gerais, p. 90.

Olivo, G.R., Archibald, D.A., Ullrich, T.D., 2011. 40Ar/39Ar evidence for the Brasiliano (ca. $500 \mathrm{Ma}$ ) tectono-thermal event in the southern margin of the São Francisco Craton: implications for the remobilization and preservation of Gold-PGE deposits hosted in the Minas Supergroup Iron-Formation. In: 11th Biennial SGA Meeting, Antofagasta, Chile, pp. 867-869.

Pagung de Carvalho, R., Rosière, C.A., Rolim, V.K., Lana, C.C., Santos, J.O.S., 2014. A sequência orosiriana-estateriana e geometria transpressiva na região de Santa Maria de Itabira-MG. Rev. Inst. Geociênc. - USP 14 (2), 101-120. 
Paslick, C.R., Halliday, A.N., Lange, R.A., James, D., Dawson, J.B., 1996. Indirect crusta contamination: evidence from isotopic and chemical disequilibria in minerals from alkali ts and nephelinites from northern Tanzania. Contrib. Mineral. Petrol. 125 (4), 277-292.

Pearce, J., Harris, N.B.W., Tindle, A.G., 1984. Trace element discrimination diagrams for the tectonic interpretation of granitic rocks. J. Petrol. 25 (4), 956-983.

Pecoits, E., 2010. Ediacaran Iron Formations and Carbonates of Uruguay: Palaeoceanographic, Palaeoclimatic and Palaeobiologic Implications. PhD thesis. University of Alberta, p. 230.

Pedrosa-Soares, A.C., Dardenne, M.A., Hasui, Y., Castro, F.D.C., Carvalho, M.V.A., 1994. Nota Explicativa dos Mapas Geológico, Metalogenético e de Ocorrências Minerais do Estado de Minas Gerais, Escala 1:1.000.000.

Pflug, R., 1968. Observações sobre a estratigrafia da Série Minas na Região de Diamantina, Minas Gerais. DNPM/DGM, Rio de Janeiro, p. 20.

Planavsky, N., Bekker, A., Rouxel, O.J., Kamber, B., Hofmann, A., Knudsen, A. Lyons, T.W., 2010. Rare earth element and yttrium compositions of Archean and Paleoproterozoic Fe formations revisited: new perspectives on the significance and mechanisms of deposition. Geochim. Cosmochim. Acta 74 (22), 6387-6405.

Polat, A., Frei, R., 2005. The origin of early Archean banded iron formations and of continental crust, Isua, southern West Greenland. Precambrian Res. 138, $151-175$.

Preinfalk, C., Kostitsyn, Y., Morteani, G., 2002. The pegmatites of Nova Era - Itabita - Ferros pegmatite district and the emerald mineralisation of Capoeirana and Belmont (Minas Gerais, Brazil) : geochemistry and Rb-Sr dating. J. S. Am. Earth Sci. $14,867-887$.

Puteanus, D., Glasby, G.P., Stoffers, P., Kunzendorff, H., 1991. Hydrothermal iron-rich deposits from the Teahitia-Mehitia and Macdonald hot spot areas. Southwest Pac. Mar. Geol. 98, 389-2409.

Ribeiro-Althoff, A.M., Cheilletz, A., Giuliani, G., Féraud, G., Barbosa Camacho, G., Zimmermann, J.L., 1997. ${ }^{40} \mathrm{Ar} /{ }^{39} \mathrm{Ar}$ and $\mathrm{K}-\mathrm{Ar}$ geochronological evidence for two periods ( 2 Ga and 650 to $500 \mathrm{Ma}$ ) of emerald formation in Brazil. Int. Geol. Rev. 39 (10), 924-937.
Rolim, V.K., Rosière, C.A., 2011. The Conceição do Mato Dentro Iron Formation Province in southeastern Brazil. In: 11th Biennial SGA Meeting, Antofagasta, Chile, pp. 927-929.

Rosière, C.A., Chemale Jr., F., 2000. Itabiritos e minérios de ferro de alto teor do Quadrilátero Ferrífero - uma visão geral e discussão. Geonomos 8 (2), 27-43.

Rosière, C.A., Spier, C.A., Rios, F.J., Suckau, V.E., 2008. The itabirites of the quadrilatero ferrifero and related high-grade iron ore deposits: an overview. Rev. Econ. Geol. 15, 223-254.

Silva, A.M., Chemale Jr., F., Kuyumjian, R.M., 1995. O ambiente tectônico dos diques máficos do Quadrilátero Ferrífero e Espinhaço Meridional e suas implicações para a evolução do Cráton São Francisco. Rev. Bras. Geociênc. 25 (2), 124-137.

Silva, L.C., Armstrong, R., Noce, C.M., Carneiro, M.A., Pimentel, M.M., PedrosaSoares, A.C., Leite, C.A., Vieira, V.S., Silva, M.A., Paes, V.J.C., Cardoso Filho, J.M., 2002. Reavaliação da evolução geológica em terrenos pré-cambrianos brasileiros com base em novos dados U-Pb SHRIMP, parte II: orógeno Araçuaí, Cinturão Mineiro e Cráton São Francisco Meridional. Rev. Bras. Geociênc. 32 (4) , 513-528.

Silveira Braga, F.C., 2012. A sequência portadora de formação ferrífera da Serra do Morro Escuro, Santa Maria de Itabira, Minas Gerais. Masters dissertation. Instituto de Geociências, Universidade Federal de Minas Gerais, p. 130.

Spier, C.A., Oliveira, S.M.B., Sial, A.N., Rios, F.J., 2007. Geochemistry and genesis of the banded iron formations of the Cauê Formation, Quadrilátero Ferrífero, Minas Gerais, Brazil. Precambrian Res. 152, 170-206.

Schöll, W.U., Fogaça, A.C.C., 1979. Estratigrafia da Serra do Espinhaço na região de Diamantina. In: SBG, Simp. Geol. MG, 1, Atas, pp. 55-73.

Taylor, S.R., McLennan, S.M., 1985. The Continental Crust: Its Composition and Evolution. Blackwell, London.

Yardley, B.W.D., 2004. Introdução à petrologia metamórfica - tradução de Reinhardt Adolfo Fuck. Editora Universidade de Brasília, Brasília.

Zacchi, E.N.P., 2010. Integração de dados aerogeofísicos, estruturais e geoquímicos para a caracterização de formações ferríferas bandadas na região de Itapanhoacanga, MG. Masters dissertation. Instituto de Geociências, Universidade de Brasília, p. 102. 